\title{
"Justiça Anormal"
}

\author{
Nancy Fraser \\ shealy@newschool.edu \\ Professor of the Politics Department \\ Henry A. \& Louise Loeb Professor of \\ Philosophy and Politics Chair \\ New School for Social Research - New \\ York \\ Recebido em15/02/2012 \\ Aprovado em 19/10/2012
}

\section{Resumo}

Este artigo disseca os parâmetros de justiça (diagnóstico) em tempos de globalização nos quais as nossas consagradas fundações (justiça normal) estão em mudança em muitos sentidos, alterando significantemente nossos conceitos (justiça anormal). Em suas considerações, o "O que", o "Quem" e o "Como" da justiça são analisados como questões de central importância, para identificar onde reconhecimento, redistribuição e representação falham ou indicam caminhos. A aproximação do tema pela autora propõe, ao final, uma visão reconstrutiva e multidimensional do tema da justiça.

\section{Tradução}

Norman Michael Rodi

\section{Palavras-Chave}

Justiça Anormal - Globalização - Revisão e Coordenação da

Reconhecimento - Representação - Tradução

Redistribuição.

Prof. Dr. Eduardo C. B. Bittar

1 Este artigo foi anteriormente publicado na Critical Inquiry 34 (primavera 2008) (C) 2008 The University of Chicago. 0093-1896/08/3403-0001\$10.00. Todos direitos reservados. Este artigo foi autorizado para tradução e publicação em língua portuguesa. 


\title{
"Abnormal Justice"
}

\author{
Nancy Fraser
}

\section{Abstract}

This article dissects the parameters of justice (diagnostic) in a time of globalization in which our accepted foundations (normal justice) are challenged in every respect, altering significantly our conceptual frame (abnormal justice). "What" constitutes a legitimate claim? Is it a case of unjust access to resources (redistribution)? The autor also questions "who" deserves legal remedies in any particular setting and "who" is affected. The stigmatized manner in which we view one another is a source of injustice, especially when crossing social, religious, cultural or political borders (recognition)? Questions as to political clout (representation) also lead to issues of abnormal justice. Furthermore, "bow" justice is structured and "bow" remedies are carried out have become a source of real concern in the justice system ranging from local courts to transnational venues. Nancy Fraser looks at a world in which decisions are no longer confined to smoke-filled rooms where the rich and politically powerful used to define, for the greater good (or for their personal/political gain), "what" counted for "whom," and "bow" justice would be carried out. She then proposes a multidimensional approach to claims (reconstructive), addressing issues of abnormal justice projecting new and fairer system.

Key words

Abnormal Justice - Globalization - Recognition Representation - Redistribution. 
Sumário

1. Núcleos de anormalidade num mundo em fase de globalização;

2. Estratégias para a teorização da justiça em tempos anormais;

2.1. O "O Quê" da justiça: paridade participatória em três dimensões;

2.2. O "Quem" da justiça: mal-enquadramento e sujeição;

2.3. O "Como" da justiça: institucionalizando a metademocracia;

3. Uma nova justiça normal ou reflexiva? Concluindo reflexões conceituais e reflexivas. 
Em alguns contextos, debates públicos que tratam de justiça assumem um disfarce de discurso normal. Por mais acirradas que sejam suas divergências quanto aos exatos requisitos jurídicos para um determinado caso, as partes compartilham algumas pressuposições quanto ao que constitui uma reclamação judicial inteligível. Essas incluem pressuposições ontológicas relativas ao(s) protagonista(s) que podem fazer este tipo de reclamação (geralmente indivíduos) e os tipos de agências a quem eles devem recorrer (tipicamente um estado). Também inclusos temos pressuposições de escopo, que fixam o círculo de interlocutores a quem reclamações por justiça devem ser dirigidas (via de regra, os cidadãos de uma comunidade política definida) e que delimita o universo daqueles cujas reclamações são merecedoras de consideração. Finalmente, os oponentes compartilham pressuposições sócioteóricas em relação ao espaço onde questões de justiça podem ser levantadas de forma inteligível (frequentemente, um espaço econômico de distribuição) e no que tange às diferenças sociais que podem dar guarida a injustiças (tipicamente elementos de classe e etnicidade). Nesses contextos, onde quem discute as questões de justiça compartilha uma base de pressuposições, suas disputas tomam forma relativamente regular e reconhecível. Constituído a partir de um conjunto de princípios organizadores e manifestando uma gramática discernível, tais conflitos assumem forma de "justiça normal".2

Claro, é questionável se o discurso da justiça é completamente normal no sentido exposto acima. É bem possível que não exista contexto no qual debates públicos relativos à justiça sejam totalmente contidos dentro de limites definidos por um quadro de pressuposições constituintes. E podemos jamais encontrar um caso em que cada participante compartilhe de todas as pressuposições. Em situações que se aproximam da normalidade, podemos suspeitar de que essas se baseiem na supressão ou marginalização dos dissidentes em relação ao consenso geral.

Não obstante, apesar desses contextos, ainda podemos falar de justiça normal de forma significativa. Analogamente, à compreensão de Thomas Kuhn de ciência normal, o discurso da justiça é normal enquanto a dissidência e desobediência pública em relação às suas pressuposições constituintes estiverem sob controle. ${ }^{3}$ Enquanto desvios permanecerem pontuais ou forem vistos como anomalias, enquanto não se acumularem e não desestruturarem o discurso, o campo de conflitos na esfera pública em questões de justiça prevalecerá como reconhecível, portanto com uma forma normal. Baseado nesse padrão, o presente contexto é de justiça anormal (Abnormal Justice). ${ }^{4}$

2 Em memória de Richard Rorty, uma inspiração em mais de uma forma.

3 Ver Thomas S. KUHN, A Estrutura das Revoluções Científicas. Chicago: University of Chicago Press, 1996.

4 Para ser estritamente fiel a Kuhn, teríamos de falar aqui de "justiça revolucionária”. Mas, dadas as associações exatas ligadas à expressão, prefiro adotar a sugestão de Rorty e falar, em vez disso, de "justiça anormal". Rorty distingue o discurso normal do discurso anormal em Richard RORTY, Filosofia e o Espelho da Natureza. Princeton: Princeton University Press, 1979; e Contingência, Ironia e Solidariedade, Cambridge: Cambridge University Press, 1989. 
À medida que proliferam debates relativos à justiça, aumenta a deficiência estrutural relativa ao discurso normal. Frequentemente, falta aos adversários de hoje uma visão comum quanto aos requisitos necessários à condição de reclamante, sejam grupos com semblantes definidos ou comunidades, enquanto outros admitem apenas indivíduos. Da mesma forma, aqueles que discutem questões de justiça nos dias de hoje, frequentemente, divergem quanto ao fórum a que devem recorrer, alguns imaginando novas instituições transnacionais ou cosmopolitas, enquanto outros restringem reclamações a estados territoriais. Também é comum que as partes de um litígio tenham opiniões divergentes quanto ao círculo público de interlocutores, com alguns dirigindo suas reclamações à opinião pública internacional, enquanto outros procuram manter as discussões dentro de um contexto local. Além disso, os contendedores de hoje, frequentemente, discordam quanto a quem tem direito à consideração da justiça, alguns pleiteando esse direito para todos os seres humanos, enquanto outros limitam suas considerações aos seus correligionários. Além do mais, ainda discordam do espaço conceitual onde questões de justiça podem surgir, alguns admitindo apenas questões econômicas de redistribuição, enquanto outros admitem, exclusivamente, questões culturais de reconhecimento e questões de representação política. Finalmente, os contendedores de hoje, frequentemente, discordam em relação às desigualdades sociais que podem dar guarida a injustiças, alguns admitindo apenas questões de nacionalidade e classe social, enquanto outros aceitam questões de gênero e sexualidade.

Resulta que os atuais debates sobre justiça têm características um tanto quanto aleatórias. $\mathrm{Na}$ ausência da força ordenadora de pressuposições partilhadas, faltam-lhes a estrutura e a forma do discurso normal. Isso fica patente em discussões informais sobre justiça na sociedade civil, onde sempre foi possível, em princípio, problematizar o dóxa - como pudemos testemunhar o exemplo das tirinhas Dinamarquesas, mais facilmente compreensível como discurso anormal sobre justiça do que como um conflito entre civilizações, de um lado, ou como um exercício de razão pública liberal, de outro. Mas anormalidade também é encontrada em fóruns institucionalizados de deliberação, assim como em tribunais e corpos de arbitragem, cuja principal função é a normalização da justiça; como pudemos testemunhar na disputa entre os juízes da Suprema Corte Americana num caso capital no tocante à admissibilidade de citações de opiniões de tribunais estrangeiros.

À medida que tais disputas em relação a premissas básicas proliferam, desvios representam menos a exceção do que a regra. Longe de se projetarem como anormalidades dentro de um campo relativamente estável de argumentação, as anormalidades invadem o quartel general do discurso jurídico. É só surgir uma disputa de primeira ordem, e ela é inundada com metadisputas em relação a pressuposições constituintes de quem conta e do que está em jogo. Não apenas questões substantivas, mas também a própria gramática da justiça está à mercê de especulações. 
Essa situação não é sem precedente. Até a reflexão mais trivial sugere alguns paralelos históricos. Um período de justiça anormal na Europa levou ao Tratado de Westfália, quando o imaginário político feudal se desenrolava, mas o sistema de estados territoriais ainda não tinha se consolidado. ${ }^{5}$ Outro exemplo é o período que se seguiu à Primeira Guerra Mundial, quando incipientes internacionalismos colidiram com nacionalismos ressurgentes entre as ruínas de três grandes impérios. ${ }^{6}$ Nesses casos, e na ausência de uma hegemonia segura e definida, paradigmas rivais entraram em conflito, e tentativas de normalizar a justiça falharam. Tais casos não são exceções. É provável, na verdade, que justiça normal seja historicamente anormal, enquanto justiça anormal represente a norma histórica. Não obstante, as anormalidades atuais são historicamente específicas, refletindo desenvolvimentos recentes, inclusive no desmantelamento da ordem da guerra fria, a contestação da hegemonia americana, o surgimento do neoliberalismo, e a nova relevância da globalização. Nessas circunstâncias, paradigmas estabelecidos tendem a desestabilizar, e reclamações por justiça se separam de ilhas preexistentes de normalidade. É o caso para as três principais famílias de reclamações judiciais: reclamações por redistribuição sócio-econômica, reclamações por reconhecimento legal ou cultural, e reclamações por representação política. Assim, seguindo a transnacionalização da produção, finanças globalizadas em mercado e regimes de investimentos neoliberais, as reivindicações por redistribuição frequentemente invadem limites de gramáticas centradas no estado em fóruns deliberativos. Da mesma forma, dadas as migrações transnacionais e o fluxo global da mídia, as reclamações, por reconhecimento de pessoas outrora distantes, assumem nova proximidade, desestabilizando horizontes de valores culturais previamente desprezados. Finalmente, numa era de contestação da hegemonia das superpotências, da governança global, e de políticas transnacionais, clamores por representação põem à prova cada vez mais o quadro anterior do estado territorial moderno. Nessa situação de desnormalização, reclamações de justiça deparam-se imediatamente com reclamações contrárias fundamentadas em bases não compartilhadas. Sejam elas uma questão de redistribuição, reconhecimento ou representação, as disputas atuais evidenciam a heteroglossia do discurso da justiça, despojadas de qualquer semblante de normalidade.

Nessa situação, as nossas teorias de justiça usuais nos oferecem pouca direção. Formuladas para contextos de justiça normal, elas focam, de modo geral, em questões de primeira ordem. O que constitui uma distribuição justa de riquezas e recursos? $\mathrm{O}$ que conta como reconhecimento recíproco ou respeito igual? $\mathrm{O}$ que caracteriza representação política justa e uma voz igual? Tomando-se como

5 Leia John Gerard RUGGIE, “Territorialidade e Além: Problematizando a Modernidade em Relações Internacionais “, Organização Internacional 47, Inverno 1993, p. 139-74.

6 Leia Hannah ARENDT, As Origens do Totalitarismo. Nova York: Columbia University Press, 1973. 
premissa uma gramática compartilhada, essas teorias não nos indicam o caminho a seguir, quando encontramos pressuposições conflitantes no que diz respeito à postura moral, a diferenças sociais e ao fórum da reivindicação. Assim, elas deixam de oferecer os recursos conceituais para lidar com problemas de justiça anormal tão características na atualidade.

Que tipo de teoria de justiça poderia servir de guia nessa situação? Que tipo de formulação teórica poderia solucionar casos em que disputas jurídicas da primeira ordem se envolvem em metadiscussões quanto à caracterização de reclamação inteligível de primeira ordem? Nesse ensaio; proponho uma abordagem de questões de (in)justiça em tempos anormais. Estrutura-se em duas partes. $\mathrm{Na}$ primeira, identificarei três núcleos de anormalidade para disputas a respeito de justiça. Depois, formularei três estratégias conceituais respectivas para esclarecer essas anormalidades. Finalmente, considerarei algumas implicações teóricas e práticas de embates contra a injustiça em tempos anormais.

\section{Núcleos de anormalidade num mundo em fase de globalização}

Começarei esboçando recente disputa relativa à justiça social. Declarando promover justiça para trabalhadores no país e no estrangeiro, sindicatos trabalhistas em países desenvolvidos se movimentam para bloquear importados que não satisfazem a padrões de produção domésticos de meio ambiente, saúde e segurança. Organizações representando os trabalhadores nos países em desenvolvimento denunciam medidas aparentemente progressistas de definir padrões atualmente inalcançáveis como uma forma injusta de protecionismo. Alvo de debates em esferas públicas domésticas e transnacionais, a primeira posição encontra apoio entre defensores da prática da justiça através de políticas democráticas no nível de estados territoriais, enquanto a segunda posição tem o apoio dos proponentes da justiça global e do mercado livre. Enquanto isso, as corporações e estados debatem questões relacionadas em fóruns jurídicos internacionais. Por exemplo, painéis de arbitragem da NAFTA recebem argumentos de uma multinacional baseada nos Estados Unidos que diz que a legislação trabalhista relativamente rígida do Canadá constitui uma barreira comercial ilegal.

O representante americano no painel de três juízes decide a favor da corporação, baseado em questões de livre comércio. O representante canadense discorda, invocando os direitos de autodeterminação do povo canadense. O representante mexicano dá o voto de Minerva a favor da corporação, tomando o lado dos Estados Unidos, mencionando o direito ao desenvolvimento do país pobre. Enquanto isso, a legitimidade dos procedimentos está em disputa. $\mathrm{Na}$ sociedade civil transnacional, ocorrem protestos contra a NAFTA e W'TO, e outras estruturas de governança da economia global. Declarando a natureza injusta e antidemocrática 
dessas estruturas, ativistas reunidos no Fórum Social Mundial debatem os contornos de uma globalização alternativa de base. Esse é um exemplo de justiça anormal (Abnormal Justice). Atravessando uma multiplicidade de arenas discursivas - algumas formais, outras informais, algumas na mídia principal, enquanto outras de forma subalterna - o local de discussão muda em velocidade alucinante. E longe de deixar de ser mencionada, a topografia do debate em si também constitui objeto em discussão. Adversários estrangeiros procuram imiscuir-se em questões de debates domésticos, enquanto nacionalistas e democratas do país procuram restringi-las ao território. Paralelamente, estados e corporações trabalham no intuito de manter disputas nos confins de instituições jurídicas regionais, ao mesmo tempo em que movimentos sociais transnacionais se empenham para ampliar a abrangência de sua discussão. Assim, a própria forma da controvérsia, incontestada no discurso normal, representa aqui um foco explícito de luta. Mesmo ao disputar questões de grande importância, os adversários ensaiam profundas discórdias em relação a quem tem o direito de fazer uma reclamação na justiça recorrendo a quem em relação a o quê; no tocante ao local e à forma de escrutínio dessas reivindicações; e questões de quem é obrigado a retificar a situação no evento de uma decisão favorável.

As anormalidades não são completamente aleatórias; no entanto, gravitam em torno de três núcleos principais. O primeiro deles reflete a ausência de uma visão comum do "o quê" da justiça. A questão aqui é a própria justiça, a substância com que se lida. Considerando o fato de que a justiça é uma relação comparativa, o que é que a justiça compara? Que pressuposições sócio-ontológicas diferenciam uma reclamação bem estruturada de uma mal estruturada? Tais questões são presumidas na justiça normal - como, por exemplo, quando todas as partes têm um conceito de justiça em termos distributivos, preocupadas com a alocação de bens divisíveis, que são tipicamente de natureza econômica. Por sua vez, em contextos anormais, o "o quê" da justiça se encontra em disputa. Aqui encontramos reclamações que não partilham de uma ontologia comum. Onde uma parte vê injustica distributiva, outra enxerga hierarquia de classe, e outro ainda vislumbra o domínio político. ${ }^{7}$ Assim, mesmo aqueles que concordam que o status quo é injusto discordam de sua caracterização.

Pressuposições divergentes quanto ao "o quê" reforçam o exemplo esboçado acima. Aí, reclamações de trabalhadores estrangeiros voltadas à desestruturação de barreiras protecionistas, que perpetuam a injustiça distributiva, entram em colisão com as reclamações políticas territoriais de cidadãos, uma vez que estes estão voltados a impedir o alastramento de políticas neoliberais que ameaçam a soberania democrática de uma entidade política fechada.

Muitas vezes, discordâncias sobre ontologia social resultam em desacordo sobre contrastes social que abrigam a injustiça. Assim, quando um lado enxerga injustiça de classe, outro vê injustiça de gênero, e outro ainda vê injustiça em termos de questões étnicas ou religiosas. 
O efeito é uma desconcertante falta de consenso, até entre democratas professos e igualitários, quanto à forma de compreensão da injustiça, sem falar dos meios de retificação. A própria questão do "o quê" da justiça está aberta a interpretações.

Um segundo núcleo de anormalidade reflete a ausência de visão comum do "quem" da justiça. Em discussão aqui está o escopo da justiça, o quadro em que se aplica. Quem conta como o sujeito da justiça numa determinada questão? Quais os interesses e necessidades de que merecem consideração? Quem pertence ao círculo daqueles merecedores de consideração igual? Essas questões são evidentes na justiça normal - como, por exemplo, quando todas as partes enquadram suas disputas como questões internas a estados territoriais, desta forma definindo o "quem" da justiça com os cidadãos de uma comunidade política delimitada. Em justiça anormal, em contraste, o "quem" não está definido. Aqui encontramos diferentes enquadramentos de disputas jurídicas. Enquanto uma parte define a questão em termos de um "quem" doméstico e territorial, outros propõem um "quem" regional, transnacional ou global. ${ }^{8}$

Pressuposições divergentes nessas questões também permeiam o exemplo esboçado acima, que trata de enquadramentos conflitantes. Aí, algumas das partes avaliam a legislação trabalhista canadense em termos de seus efeitos domésticos, enquanto outros consideram os efeitos no território ampliado da América do Norte, e ainda outros procuram mais adiante em termos dos interesses de trabalhadores de países em desenvolvimento ou até da comunidade global de seres humanos. $\mathrm{O}$ resultado é a falta de consenso no sentido de quem conta. Não só a questão do "o quê" da justiça, mas o "quem” está em aberto à interpretação.

O terceiro núcleo de anormalidade reflete a falta de visão compartilhada do "como" da justiça. Aqui a questão é a essência processual. Como, em um dado processo, devemos definir a gramática apropriada para refletir sobre a justiça? Que critérios ou processos de decisão devem resolver disputas em relação aos "o quê" e aos “quem”? Na justiça normal (Normal Justice), essas questões não aparecem por definição, sendo que o "o quê" e o "quem" não estão em disputa. Em contextos anormais, em contraste com ambos os parâmetros em pauta, discordâncias em

8 Frequentemente, a discordância sobre o âmbito da questão resulta em desacordo sobre a âmbito do fórum, ou seja, sobre o público envolvido e diante do qual uma questão judicial é debatida legitimamente. Portanto, em contextos anormais para a resolução de questões de justiça, é comum a adoção, por uma parte, de um público delimitado a um territótio, enquanto a outra parte pode recorrer a públicos regionais, transnacionais ou globais. 
relação ao "como" certamente virão à tona. Aqui, encontramos cenários conflitantes para a resolução de disputas. Onde uma parte invoca a autoridade de um tratado interestadual, outras apelam para as Nações Unidas, a balança do poder, ou para os procedimentos institucionalizados de uma democracia cosmopolita que ainda está por ser inventada. ${ }^{9}$

A incerteza em relação ao "como" reforça o exemplo esboçado acima. Ali, estados e corporações apelam à NAFTA para obter uma solução, enquanto ativistas anti-neoliberais identificam uma luta popular transnacional para influenciar a opinião pública global. Enquanto os primeiros apelam para uma arena regional, baseada em tratados para a resolução de suas questões jurídicas, o segundo grupo procura o Fórum Social Mundial que não tem autoridade institucional para decidir e garantir a execução de suas decisões. Aqui, portanto, não há consenso quanto a como disputas relativas à gramática da justiça devam ser resolvidas. Não é apenas o "o quê" e o "quem", mas também o "como" da justiça que está em aberto à interpretação.

Juntos, esses três núcleos de anormalidade refletem a desestabilização da antiga gramática hegemônica. As incertezas de hoje em relação ao "o quê" refletem a descentralização da definição de substância de justiça daquela gramática. O que foi problematizado aqui é a visão que identifica a justiça exclusivamente com a distribuição justa de bens econômicos. Essa compreensão predominou na formulação de argumentos nas décadas que se seguiram à Segunda Guerra Mundial. Na base de culturas políticas normalmente divergentes, do comunismo da Segunda Guerra Mundial e do desenvolvimentismo do Terceiro Mundo, a clara interpretação do "o $q u \hat{e}$ " tendia a marginalizar as injustiças alheias ao âmbito econômico. Projetando a distribuição desigual como a injustiça quintessencial, disfarça injustiças de falta de reconhecimento, embasadas em hierarquias de status, assim como injustiças de falta de representação, presentes na constituição política da sociedade. ${ }^{10}$

Analogamente, as incertezas de hoje em relação ao "o quê" refletem a desestabilização da antiga estrutura gramatical. Nesse caso, o que foi problematizado é a visão westfaliana de que o Estado territorial moderno é a entidade única na qual a justiça se aplica. Essa visão enquadrou a maior parte do discurso jurídico no pós-guerra. Em conjunção com o conceito de distribuição, organizou culturas normalmente divergentes em todo o mundo, apesar das mensagens para os direitos

9 Frequentemente, divergências processuais resultam em disputas sobre representação ou voz política. Enquanto uns preferem restringir a representação a entidades deliberativas governamentais, outros propõe a representação através de ONGs, e ainda outros vislumbram esquemas cosmopolitas democráticos para representar indivíduos como cidadãos do mundo.

10 Este quadro tendia a marginalizar reclamações referentes a linhas de fraturas sociais que não de classe, incluindo gênero, sexualidade, religião e raça ou etnia. 
humanos, proletarianismo internacional e solidariedade do Terceiro Mundo. ${ }^{11}$ Com uma efetiva territorialização da justiça, o quadro westfaliano equacionou o escopo da questão com a cidadania de uma comunidade política delineada. Como efeito, obrigações legais, atravessando fronteiras, foram drasticamente limitadas, ou totalmente anuladas. Construindo um conjunto de "quem" domésticos ligados ao território, discretos e dispostos lado a lado, esse quadro despreza justiças transfronteiriças. ${ }^{12}$

Finalmente, a incerteza nos dias de hoje em relação do "como" reflete a nova visibilidade da antiga característica velada da gramática pós-guerra. O que se tornou visível, e por isso contestável, é uma pressuposição hegemônica encoberta.

Enquanto pressuposições distributivistas westfalianas dominavam o discurso de justiça, não havia uma percepção clara das instituições e procedimentos necessários para resolver disputas quanto ao "o quê" e ao "quem”. Naquelas ocasiões, quando tal necessidade foi sentida, presumia-se que estados poderosos e uma elite privada resolveria as discussões em organizações intergovernamentais ou em reuniões enfumaçadas a portas fechadas. O efeito foi o de dissuadir contestações democráticas abertas do "o quê" e do "quem".

Hoje, no entanto, nenhuma dessas pressuposições normalizadoras está garantida. A hegemonia do "o quê" distributivo já sofre contestações partindo de pelo menos dois lados: primeiro, por diversos agentes da política do reconhecimento, desde multiculturalistas que procuram acomodar diferenças, a etno-nacionalistas que procuram eliminá-las; e, segundo, por diversos agentes da política da representação, desde feministas em campanha por cotas de gênero no rol de candidatos a minorias nacionais pleiteando seu lugar no cenário do poder. Em consequência, temos agora pelo menos três conceitos antagônicos do que representa o "o quê" da justiça: redistribuição (redistribution), reconhecimento (recognition) e representação (representation).

11 Alguns leitores sugerem que povos colonizados nunca aceitaram a legitimidade do quadro westfaliano, portanto, que essa estrutura nunca foi verdadeiramente normalizada. Na minha opinião, no entanto, a grande maioria dos anti-colonialistas no mundo pós-II Guerra Mundial procuravam constituir estados independentes próprios nos moldes westfalianos. Em contraste, apenas uma pequena minoria defendia consistentemente a justiça dentro de moldes globais - por razões que são inteiramente compreensíveis. Minha posição é, portanto, que, longe de contestar o quadro Westfaliano em sí, forças anti-imperialistas geralmente preferiam empregá-lo de forma verdadeiramente universal, imparcial e equilibrada. Meus agradecimentos a Ann Laura Stoler por forçar o debate sobre esta questão, mesmo sabendo que ela não ficará satisfeita com a minha resposta.

12 O quadro Westfaliano também conteve debates públicos sobre justiça dentro dos limites de um estado. Canalizando reivindicações jurídicas para as esferas públicas internas de estados territoriais, o debate público transnacional em matéria de justiça foi desencorajado. 
Enquanto isso, a hegemonia do "quem" westfaliano já sofre contestações partindo de pelo menos três lados: primeiro, por localistas e comunitaristas, que procuram localizar o escopo da questão em unidades subnacionais; segundo, por regionalistas e transnacionalistas, que se propõem a identificar o "quem" da justiça em unidades maiores, mas não universais, como a Europa ou o Islã; e, terceiro, por globalistas e cosmopolitas, que se propõe a dar consideração igual a todos os seres humanos. Em consequência, temos agora na mesa pelo menos quatro visões diversas do "quem" da justiça: westfaliana, local-comunitarista, transnacionalregional, e global-cosmopolita.

Finalmente, a oscilação silenciosa do "como" hegemônico foi contestado através de um crescimento geral das expectativas democráticas, à medida que mobilizações de todas essas facções exigiam a palavra na discussão do "o quê" e do "quem". Ao contestar as instituições e os quadros, esses movimentos contestam efetivamente as prerrogativas dos estados e elites de determinar a gramática da justiça. Promovendo discussões amplas a respeito do "o quê" e do "quem", eles colocaram em jogo, ao lado de pressuposições hegemônicas, visões populistas e democráticas do "como" da justiça.

O surgimento de perspectivas rivais do "o que", do "quem" e do "como" representa um problema sério para quem se preocupa com a justiça nos dias de hoje. De alguma forma, precisamos trabalhar essas questões de metadisputas sem perder de vista os problemas de justiça de primeira ordem. Mas, com todos os parâmetros em jogo simultaneamente, não temos um solo firme sobre o qual nos apoiar. A anormalidade nos confronta em cada curva.

\section{Estratégias para a teorização da justiça em tempos anormais}

Que tipo de teoria de justiça poderia nos guiar nessa situação? Para encontrar uma resposta convincente, precisamos começar com uma visão equilibrada da questão em pauta. A chave, acredito, é apreciar tanto o lado positivo quanto o lado negativo da justiça anormal. O lado positivo é a expansão do campo da contestação, daí a oportunidade de repudiar injustiças que a gramática costumava elidir. Por exemplo, a descentralização do "o quê" distributivo torna visíveis e vulneráveis a críticas, prejuízos não econômicos relativos ao não reconhecimento e à não representação. Da mesma forma, a desnormalização do "quem" westfaliano torna concebível a até então obscura forma de meta-injustiça, possivelmente chamada de mal-enquadramento, em que questões de justiça de primeira ordem são enquadradas de forma errônea - como no caso em que um enquadramento nacional de questões distributivas rejeita as reivindicações das classes destituídas globais. ${ }^{13}$

Discutirei o enquadramento em maior detalhe na seção 2.2 abaixo. 
Se assumirmos, como acredito que devemos, que o mal-reconhecimento, a má-representação e o mal-enquadramento pertençam, em princípio, ao genuíno catálogo de injustiças, então a desestablilização de uma gramática que os suprimiu deve ser vista como um desenvolvimento positivo. Aqui, então, temos o lado bom da justiça anormal: a expansão das possibilidades de se contestar injustiças. Mas justiça anormal também tem seu lado negativo. O problema é que a contestação expandida não pode, por si só, debelar as injustiças. Para isso é necessário se acrescentar pelo menos duas condições: primeiro, um quadro relativamente estável em que reclamações possam ser analisadas de forma justa e, segundo, agências institucionalizadas e formas de retificação. Ambos os elementos acima estão presentes na justiça anormal (Abnormal Justice). Como devemos examinar reivindicações de forma justa e retificar injustiças de forma legítima em contextos em que o "o quê", o "quem", e o "como" estão em disputa? Aqui temos, então, o lado negativo da justiça anormal: em meio a contestações expandidas, temos menos meios efetivos de reconhecer e retificar injustiças.

Quem se propõe a tecer suas teorias a respeito da justiça em tempos anormais deve manter o foco nos dois lados da equação. Que tipo de teoria poderia, ao mesmo tempo, valorizar a maior contestação e fortalecer a menor capacidade de julgamento e de determinação de medidas compensatórias. Sem falsas pretensões de apresentar uma resposta completa, proponho que se procure por sinais reexaminando os três núcleos de anormalidade descritos acima. Considerados individualmente, cada um tem uma mensagem importante quanto à interpretação do conceito de justiça em tempos anormais.

\section{1. $\mathrm{O}$ "O quê" da justiça: paridade participatória em três dimensões}

Considere, primeiro, o problema do “o quê". Aqui, a questão é: que tipo de abordagem pode validar a contestação de distributivismo redutivo, enquanto também esclarece perspectivas para a resolução de disputas que englobam conceitos antagônicos de justiça? A resposta resumida é uma estratégia que combina a ontologia social multidimensional com o monismo.

\section{Permita-me esclarecer.}

Com o intuito de dar validade à maior contestação, a teoria da justiça deve propor-se a oferecer uma audiência justa para acolher as reivindicações das partes. Para evitar a rejeição antecipada de demandas, a teoria deve ter a habilidade de lidar com casos que pressupõem perspectivas fora do padrão quanto ao "o que" da justiça. Salientando o lado inclusivo, então, devemos começar com a suposição de 
que a injustiça se apresente em mais de uma forma e que nenhuma perspectiva do "o quê" pode satisfazer a todas. Rejeitando o monismo sócio-ontológico, essa visão deve enxergar a justiça numa multiplicidade de dimensões, cada uma associada com um gênero analiticamente distinto de injustiça e revelada através de uma forma distinta de contenda social.

Considere três possibilidades a que eu já aludi. Como visto, primeiramente, do ponto de vista de movimentos trabalhistas, a justiça contém dimensão econômica, enraizada na política econômica, cuja injustiça associada é a má-distribuição, ou a desigualdade de classes. Por outro lado, da perspectiva de movimentos multiculturalistas, a justiça engloba dimensão cultural, enraizada na ordem do status, cuja injustiça correspondente é o mal-reconhecimento ou o status hierárquico. Como vimos, finalmente, através da lente dos movimentos de democratização, a justiça inclui uma dimensão política, enraizada na constituição política da sociedade, cuja injustiça é a da má-representação ou a falta de expressão política.

Aqui temos, então, as três perspectivas diferentes do "o que da justiça. Enquanto cada uma corresponde a uma forma autêntica de injustiça que não pode ser reduzida a outras, nenhuma pode ser excluída legitimamente da formulação de teorias contemporâneas. Assim, o monismo ontológico em relação a injustiças é profundamente equivocado. ${ }^{14}$ Contra aqueles que insistem em uma versão monística única do "o quê", é melhor enxergar a justiça como um conceito multidimensional que engloba as três dimensões, de redistribuição, reconbecimento e representação. ${ }^{15}$ Esse conceito é especialmente útil em tempos anormais.

Apenas com a pressuposição desde o início de que reivindicações são inteligíveis nas três dimensões, podemos oferecer uma audiência justa a todas as partes envolvidas em disputas que contenham visões diversas do "o quê".

14 Dois exemplos, em extremidades opostas do espectro filosófico, são Ronald Dworkin e Axel Honneth. Dworkin sustenta que todas as injustiças se reduzem no final a questões de má distribuição, enquanto Honneth sustenta que todos, no fundo, são variantes de mal reconhecimento. Para a perspectiva de Dworkin, ver Ronald DWORKIN, O que é a Igualdade? Parte 2: Igualdade de Recursos, Filosofia e Relações Públicas, 10, Outono 1981, p. 283-345. Para uma crítica, ver Elizabeth S. ANDERSON, Qual é o Ponto de Igualdade? Ética 109, janeiro 1999, p. 287-337. Para visão de Honneth, leia Axel HONNETH, Redistribuição ou Reconhecimento: Uma Resposta a Nancy Fraser, em Nancy FRASER e Axel HONNETH, Redistribuição ou Reconhecimento? Um Intercâmbio Político-Filosófico, trad. Joel Golb, James Ingram, e Christiane Wilke, London: Verso, 2003, pág. 110-97. Para uma crítica, ver FRASER, Distorcido além de Qualquer Reconhecimento: Uma Tréplica ao Axel Honneth, em Redistribuição ou Reconhecimento? pp 198-236.

15 Para uma maior elaboração e defesa deste ponto de vista, leia FRASER, Justiça Social na Era da Política de Identidade, em FRASER e HONNETH, Redistribuição ou Reconhecimento? London: Verso, 2003, pág. 7-109. 
Mas por que apenas três? Os exemplos apresentados há pouco sugerem que, ao invés de serem analisados todos de uma só vez, as dimensões da justiça se revelam historicamente, através dos meios de luta social. Nessa visão, movimentos sociais revelam novas dimensões de justiça quando são bem sucedidos em estabelecer reivindicações plausíveis que transgridem a gramática estabelecida da justiça normal que, em retrospecto, aparentam ter suprimido as desvantagens sofridas por seus membros. Porém, no momento que antecede uma nova compreensão do "o quê" de forma mais inteligível, a irrupção de reclamações transgressivas vem a causar um discurso anormal (abnormal discurse). ${ }^{16}$ Nessas ocasiões, continuamos a questionar se uma nova dimensão de justiça está no processo de se revelar. Segue que qualquer tentativa de formular teorias de justiça nessas condições deve permitir essa possibilidade. Qualquer um que recusa um caso em bases dogmáticas expõe um raciocínio inadequado para o momento atual.

O que segue para uma teoria de justiça para tempos anormais? Primeiramente, devemos praticar caridade hermenêutica com respeito às visões fora do padrão do que representa o "o que" por parte dos reclamantes, conferindo a eles a presumida inteligibilidade e a potencial validade de seus argumentos. Ao mesmo tempo, a teoria deve testar estas visões assegurando se realmente expõe formas genuínas de injustiça desprezadas pela antiga gramática e, se for o caso, se essas novas formas reveladas estão enraizadas em dimensões de ordem social negligenciadas até o momento. ${ }^{17}$ No contexto atual, isso significa a aceitação de reclamações, como bem estruturadas e inteligíveis em princípio, estruturadas, no mínimo, em três perspectivas distintas do "o quê" da justiça: redistribuição, reconbecimento, e representação. ${ }^{18}$ Provisoriamente, acolhendo a perspectiva tridimensional da justiça, centrada na economia, cultura e política, a teoria deve, no entanto, se manter aberta à inclusão de novas dimensões através da luta de classes.

Por si só, no entanto, uma ontologia social multidimensional não é a solução. Assim que admitirmos múltiplos gêneros de injustiça, precisaremos de uma forma de formalizá-los dentro de uma medida. Assim, precisamos de um princípio

16 Para um tratado da segunda onda de feminismo nesses contornos, leia RORTY, Feminismo e Pragmatismo, Michigan Quarterly Review 30, Primavera 1991, p. 231-58.

17 O teste que estou propondo tem dois aspectos, um moral-filosófico, e o outro social-teórico. Do ponto de vista da filosofia moral, a questão é: Será que a nova proposta de interpretação do "o quê" da justiça identifica uma injustiça genuína que viola uma norma moral válida? Do ponto de vista da teoria social, a questão é: Será que a nova proposta de interpretação expõe algum tipo de obstáculo institucional à paridade participativa enraizada em uma dimensão de ordem social antes negligenciada?

18 Como a nota anterior sugere, existe outra linha de raciocínio social-teórica implícita nessa discussão para uma visão tridimensional do "o quê". Sociedades modernas abrangem três dimensões distintas de ordem social: econômica, hierárquica, e política. Nenhuma delas pode ser reduzida às outras, e cada uma pode gerar injustiças. Para uma discussão mais completa, leia FRASER, Justiça Social na Era da Política de Identidade, em FRASER e HONNETH, Redistribuição ou Reconhecimento? London: Verso, 2003. 
normativo válido para todos. Sem esse princípio de unificação, não temos meios de avaliar reivindicações com implicações multidimensionais, portanto, não temos uma forma de processar disputas que englobam múltiplas perspectivas do "o quê".

Qual seria o aspecto de tal princípio? Minha proposta é a de sujeitar cada caso em todas as três dimensões ao princípio normativo inclusivo de paridade participativa. Conforme esse princípio, a justiça requer estruturas que permitam a todos participar como iguais na vida social. ${ }^{19}$ Uma visão de justiça, em termos de paridade participativa, representa o desmantelamento de obstáculos institucionalizados que impedem que certas pessoas participem no mesmo nível com outros, como parceiros plenos, em ações sociais. Conforme sugerido nas discussões acima, tais obstáculos podem se apresentar de três formas distintas. Na primeira, as pessoas podem ser impedidas de participar efetivamente por estruturas econômicas que lhes rejeitam os meios necessários para interagir com outros como iguais; nesse caso, sofrem de injustiça distributiva ou má-distribuição. $\mathrm{Na}$ segunda, as pessoas podem ser impedidas de interagir em termos de paridade por meio de hierarquias institucionalizadas, de valor cultural que lhes nega a posição necessária; nesse caso, eles sofrem de desigualdade em termos de status ou mal-reconhecimento. ${ }^{20} \mathrm{Na}$ terceira, pessoas podem ser impedidas de praticar uma participação plena por regras estabelecidas, negandolhes a igualdade em deliberações públicas e na tomada de decisões democráticas; nesse caso, eles sofrem de injustiça política ou má-representação. ${ }^{21}$

Aqui, portanto, temos uma situação em que três formas diferentes de injustiça levam a um resultado comum: em cada caso, alguns atores sociais são impedidos de participar de forma igual com outros em interações sociais. ${ }^{22}$

19 Eu elaborei e defendi este princípio em FRASER, Justiça Social na Era da Políticas de Identidade, em FRASER e HONNETH, Redistribuição ou Reconhecimento? London: Verso, 2003.

20 Este modelo de estatus de reconhecimento representa uma alternativa para o modelo de identidade padrão. Para uma crítica desta última e uma defesa do anterior, ver Fraser, "Repensando o Reconhecimento", New Left Review 3, maio-junho 2000, p. 107-20.

21 A incorporação da representação política como uma terceira dimensão da justiça constitui uma revisão importante da minha estrutura, originalmente bidimensional. Para uma explanação desta dimensão, e as minhas razões para incluí-la, leia FRASER, Reenquadrando a Justiça num Mundo Globalizado, New Left Review 36, novembro-dezembro 2005, p. 69-88. leia também FRASER, Identidade , Exclusão e Crítica: Uma Resposta a quatro críticos, European Journal of Political Theory 6, julho 2007, p. $305-38$ e "A Política do Enquadramento: Uma Entrevista com Nancy Fraser, Entrevista de Kate Nash e Vikki Bell, Teoria, Cultura e Sociedade 24, número. 4 2007, p. 73-86.

22 No primeiro caso, o problema surge a partir da estrutura econômica da sociedade, que corresponde à dimensão econômica da justiça. No segundo caso, o problema é de ordem hierárquica, que corresponde à dimensão cultural. No terceiro caso, o problema é a constituição do sistema político, que corresponde à dimensão política da justiça. 
Assim, todas as três formas de injustiça violam um princípio único, o princípio de paridade participativa. Esse princípio cobre as três dimensões e serve para tornálos comensuráveis. ${ }^{23}$

Os detalhes exatos dessa situação são menos importantes do que a estrutura geral do conceito. O que é realmente importante aqui é que essa perspectiva do " 0 $q u e ̂$ " da justiça combina a multidimensionalidade da ontologia social com monismo normativo. Como resultado, leva em conta os dois lados da justiça anormal, tanto a negativa, quanto a positiva. Graças à sua multidimensionalidade ontológica, a contestação da normalização distributiva é validada. Estipulando que o malreconhecimento e a má-representação constituam injustiças genuínas em princípio, essa perspectiva oferece audiência justa para reclamações que transgridem a antiga gramática. Ao mesmo tempo, graças ao seu monismo normativo, essa estratégia reúne os três gêneros de injustiça numa só medida. A sujeição de uma reivindicação por redistribuição, reconbecimento e representação ao princípio de paridade participativa global cria um espaço discursivo único que pode acolher a todos. Assim, esse meio oferece a possibilidade de avaliação de casos em condições de discurso anormal, onde múltiplas perspectivas do "o quê" da justiça estão em jogo.

No entanto, importante questão perdura. Paridade de participação entre quem? Quem exatamente tem o direito de participar no mesmo nível com quem e em que interações sociais? A não ser que obtenhamos uma forma adequada de entender o "quem" da justiça, esse método em relação ao "o quê" não será útil.

23. Podemos questionar: Por que a paridade participativa, em oposição aos princípios rivais de proporcionalidade? Sem falsas pretensas de apresentar uma defesa completa aqui, permita apenas que eu aponte que esta noção tem uma afinidade eletiva com a problemática da justiça anormal. Quando os parâmetros básicos de justiça são contestados, carecemos de padrões de avaliação dos méritos em relação a reclamações de justiça. Efetivamente tomados de surpresa em critérios processuais, não temos alternativa se não imaginar situações em que todas as partes podem interagir com as outras em condições justas. Em tais casos devemos nos perguntar: Será que todos os interessados têm chances iguais de participar plenamente, em condições de paridade? Ou seriam alguns excluídos ou marginalizados em conseqüência de estruturas sociais injustas, que institucionalizam barreiras estruturais à participação? Assim, o princípio da paridade participativa nos leva ao questionamento de arranjos sociais, para descobrir, e criticar, barreiras entrincheiradas ao engajamento justo. Como princípio de medição padrão, ressaltamos, serve como medida para a avaliação de reivindicações de justiça em todas as três dimensões. Para cada dimensão, apenas as reclamações que promovem a paridade de participação são moralmente justificadas. Idependentemente da questão dizer respeito à distribuição, reconhecimento, ou representação, aqueles que afirmam ter sofrido alguma injustiça devem demonstrar, primeiro, que disposições atuais os impedem de participar em condições de igualdade na vida social e, segundo, que as soluções propostas viriam a reduzir essas disparidades. Além disso, o padrão de paridade se aplica trans-categoricamente, através das diferentes dimensões de justiça; um pode usá-lo, por exemplo, para avaliar o impacto das propostas de reformas econômicas sobre condições sociais ou vice-versa. Da mesma forma, o padrão de paridade se aplica recursivamente, através de diferentes eixos de subordinação, sendo possível usá-lo, por exemplo, para avaliar os efeitos sobre as relações de gênero de formas propostas de reconhecimento etnocultural ou vice-versa. Para uma descrição mais completa de tais complexidades, leia FRASER, Justiça Social na a Idade da Política de Identidade, em FRASER e HONNETH, Redistribuição ou Reconhecimento? London: Verso, 2003. 


\subsection{O “Quem” da justiça: mal-enquadramento e sujeição}

Considero, analogamente, o segundo núcleo de justiça anormal, no que tange o "quem”. Para essa questão, saliento a necessidade preeminente de considerar tanto do lado positivo quanto do lado negativo da justiça anormal. Que tipo de formulação teórica pode valorizar a contestação do quadro westfaliano ao mesmo tempo em que esclarece disputas que englobam perspectivas antagônicas em termos de quem conta? A resposta resumida sugere uma formulação teórica que é, ao mesmo tempo, reflexiva e determinante.

\section{Permita-me esclarecer.}

Com o intuito de valorizar contestações mais frequentes, a reflexão e a justiça anormal devem estar abertas a alegações de que questões de justiça de primeira ordem tenham sido erroneamente enquadradas. Para assegurar que esses casos recebam audiência justa, devemos presumir, a princípio, que injustiças de malenquadramento possam existir. Assim, a formulação de teorias a respeito da justiça anormal (Abnormal Justice) devem ser reflexivas. Para aplicar o princípio de paridade participativa às questões de primeira ordem referentes à distribuição, ao reconhecimento e à representação, devemos nos projetar para o nível seguinte, onde o quadro em si está em discussão. É só através da reflexão que se pode entender a questão do "quem" como uma questão de justiça. Como podemos gerar a reflexividade necessária na justiça anormal? A estratégia que proponho esboça um conceito distinto da dimensão política.

Até agora, considerei essa dimensão da forma usual, como se envolvida exclusivamente com injustiças ordinárias de má-representação política. Essas são injustiças políticas que provém de uma comunidade política com contornos e membros supostamente estáveis. Assim, a má-representação política ordinária ocorre quando regras de uma entidade política quanto à tomada de decisões impedem que pessoas que sejam, em princípio, membros, participem de forma plena, como iguais. Recentemente, tais injustiças resultaram em demandas por mudanças na modalidade de representação política ordinária - variando desde reivindicações por cotas de gênero em listas eleitorais, direitos multiculturais, autogoverno indígena, autonomia de províncias, de um lado, a demandas por reformas nas contribuições de campanhas políticas, mudanças de zoneamento distrital, representação proporcional, e votação cumulativa, de outro. ${ }^{24}$

24 Para discussões sobre essas questões, leia R. RITCHIE e S. HILL, Em Defesa da Representação Equitativa, em Os Votos de Quem Contam? Boston: ed. Ritchie e Hill, 2001, pág. 1-33; Lani GUINIER, A Tirania da Maioria: Justiça Fundamental na Democracia Representativa, Glencoe: The Free Press of Glencoe, 1995; M. Shirin Rai, "Representação Política, Instituições Democráticas e o Empowerment da Mulher: O Debate de Cotas na Índia", em Repensando o Empowerment: Gênero e Desenvolvimento em um Mundo Global / Local, Londres: ed. Jane L. Parpart, Rai, e Kathleen Staudt, 2000; Grupos de Identidade, Perspectivas sobre Política 2, Set. 2004, p. 439-58; Will KYMLICKA, Cidadania Multicultural: Uma Teoria Liberal de Direitos das Minorias, Oxford: Oxford, 1995; e Melissa WILLIAMS, Voz, Confiança e Memória: Grupos Marginalizados e as Falhas da Representação Liberal Princeton:N.J., 1998. 
Por mais importante que sejam, essas questões constituem apenas metade da história. Além da injustiça política ordinária que se manifesta dentro do quadro de uma entidade política delimitada podemos, também, vislumbrar outro nível, digamos, uma injustiça metapolítica, que resulta da divisão de espaços políticos em entidades definidas. Esse segundo nível inclui injustiças de mal-enquadramento. Tais injustiças ocorrem quando as delimitações de uma entidade política são estabelecidas de tal forma a negar a algumas pessoas a oportunidade de participar em todos os seus concursos autorizados pertinentes à justiça. Nesses casos, aqueles que se caracterizam como não membros são erroneamente excluídos do universo daqueles merecedores de reconhecimento dentro da entidade política no que tange questões de distribuição, reconhecimento e representação política ordinária. A injustiça permanece, posso salientar, até quando os excluídos de uma comunidade política se encontram incluídos em questões de justiça em outra - considerando que o loteamento político tem o propósito de colocar alguns meios relevantes de justiça fora do seu alcance. Um exemplo é a forma com que o sistema internacional de estados soberanos iguais manipula o espaço político à custa das classes destituídas do mundo.

Apesar do termo em si não ser utilizado, a noção de mal-enquadramento informa implicitamente as reivindicações de muitos ativistas de "globalização alternativa" associados com o Fórum Social Global. Em sua visão, o quadro westfaliano é injusto, já que divide o espaço político de forma a impedir a possibilidade de muitas pessoas que são pobres e desprezadas de fazer frente às forças que as mantêm oprimidas. Canalizando as reclamações para espaços políticos domésticos de estados relativamente impotentes, se não completamente fracassados, esse quadro protege governos estrangeiros de críticas e de controle. ${ }^{25}$ Dentre aqueles governos blindados dos braços da justiça, estão os estados predadores mais poderosos e poderes privados transnacionais, inclusive investidores e agentes de crédito estrangeiros, especuladores de moedas internacionais, e corporações transnacionais. ${ }^{26}$

25 Leia Thomas W. POGGE, A Influência da Ordem Mundial sobre as Perspectivas para uma Verdadeira Democracia em Países em Desenvolvimento, Ratio Juris 14, setembro 2001, p. 326-43 e Justiça Econômica e Fronteiras Nacionais, Revision 22, Outono 1999, p. 27-34; e Rainer FORST, Para uma Teoria Crítica de Justiça Transnacional, em Justiça Global, Oxford: ed. Pogge, 2001, p. 169-87 e Justiça, Moralidade e Power e no Contexto Global, em Justiça no Mundo Real: Fundamentos, Princípios, Direitos Humanos, e as Instituições Sociais, Dordrecht, Holanda: ed. Andreas Follesdal e Pogge, 2005, p. 27-36.

26 Leia Richard L. HARRIS e Melinda J. SEID, Perspectivas Críticas sobre Globalização e o Neoliberalismo em Países em Desenvolvimento, Boston: Brill, 2000, e Ankie HOOGVELT, Globalização e o Mundo Pós-colonial: a Nova Economia Política do Desenvolvimento, Baltimore: Johns Hopkins University Press, 2001. 
Também protegidas estão as estruturas de governança da economia global, que impõem um regime de exploração, ao mesmo tempo em que impedem o surgimento de um controle democrático. ${ }^{27}$ Finalmente, o quadro westfaliano é autoisolador, já que a arquitetura do sistema interestadual exclui tomadas de decisões democráticas transnacionais em questões de justiça. ${ }^{28}$

Essas são, de qualquer maneira, as posições de alguns ativistas do Fórum Social Global.Sua preocupação recai em nosso segundo nível de justiça, no nível metapolítico, que engloba injustiças de mal-enquadramento. Alertados à possibilidade de que enquadramentos de justiça de primeira ordem também podem ser injustos, esse nível lida com a questão do quadro como questão de justiça. Resulta uma reflexão necessária para analisar disputas referentes ao "quem" na justiça anormal.

Isoladamente, porém, a reflexão não constitui solução. Assim que aceitamos que injustiças de mal-enquadramento possam em princípio, existir, torna-se necessário algum meio de determinar se existem de fato e onde. Assim, a teoria da justiça para tempos anormais requer um princípio normativo determinante para a avaliação dos quadros. $\mathrm{Na}$ ausência de tal princípio determinante, não há como avaliar as alternativas, portanto não há meios de esclarecer disputas que envolvem conceitos antagônicos do "quem".

27 Leia Robert W. COX, Uma Perspectiva sobre a Globalização, em Globalização: Reflexões Críticas, Boulder: ed. James H. Mittelman, 1996, p. 21-30 e Democracia em Tempos Difíceis: Globalização Econômica e as Limitações à Democracia Liberal, em A Transformação da Democracia? Cambridge: ed. Anthony McGrew 1997, p. 49-72; Stephen GILL, Novo Constitucionalismo, Democratização e Política Econômica Global, Pacific Review 10, fevereiro 1998, p. 23-38; Eric HELLEINER, De Bretton Woods a Financas Globais: O Mundo de Cabeça para Baixo, em Economia Política e a Transformação da Ordem Mundial, Nova York: ed. Richard Stubbs e Geoffrey RD Underhill, 1994, p. 163-75; David SCHNEIDERMAN, Regras de Investimento e as Regras da Lei, Constellations 8, Dez. 2001, p. 521-37; Alfred C. AMAN, Jr.," Globalização, Democracia e a Necessidade de uma Nova Lei de Administração, Indiana Journal of Legal Global Studies 10, Inverno 2003, p. 125-55; Servaas STORM e J. Mohan RAO, A globalização de Mercado e a Democracia Munidial: Podem as Vertentes se Encontrar?, Desenvolvimento e Mudança 35, Junho de 2004, p. 567-81, e James K. BOYCE, Democratizando a Governança Econômica Global, Desenvolvimento e Mudança 35, Junho de 2004, p. 593-99.

28 Leia John S. DRYZEK, A Democracia Transnacional, Journal of Political Philosophy 7, março 1999, p. 30-51; James BOHMAN, Regimes Internacionais e Governança Democrática: Igualdade Política e Influência em Instituições Mundiais, International Affairs 75, Julho de 1999, p. 499-513; e David HELD, Regulando a Globalização? A Reinvenção da Política, International Sociology 15, junho de 2000, p. 394408, Democracia e Ordem Global: Do Estado Moderno para Governança Cosmopolita Cambridge, 1995, p. 99-140, A Transformação da Comunidade Política: Repensando a Democracia no Contexto da Globalização, em Fronteiras da Democracia, Cambridge: ed. Ian Shapiro e Casiano Hacker-Cordo'n, 1999, p. 84-111, Cosmopolitismo: Globalização Domesticada? Review of International Studies 29, outubro 2003, p. 465-80, e Responsabilidade Democrática e Eficácia Política da Perspectiva Cosmopolita, Governo e Oposição 39, Primavera 2004, p. 364-91. 


\section{Como seria um princípio determinativo para a avaliação de quadros?}

Atualmente, temos três candidatos principais. Proponentes do princípio de membro sugerem resolver as disputas em torno do "quem" apelando para critérios de filiação política. Para eles, por conseguinte, o que torna um conjunto de indivíduos um grupo de iguais, sujeitos às mesmas leis e à cidadania compartilhada, ou à nacionalidade compartilhada. ${ }^{29}$ Pelo fato de esse método estabelecer quadros com base em filiação política, ele tem a vantagem de ser fundado numa realidade institucional existente e/ou de ampla identificação coletiva. No entanto, sua força também é sua fraqueza. Na prática, o princípio da filiação serve convenientemente à ratificação do nacionalismo exclusivista para os ricos e poderosos - daí protegendo quadros estabelecidos de escrutínio crítico.

Não é, pois, de se admirar que alguns filósofos e ativistas escolham o princípio de humanismo. Procurando um padrão mais inclusivo, propõem resolver disputas quanto ao "quem" seguindo critérios de pessoa. Para eles, por conseguinte, o que faz de um grupo de indivíduos um grupo de pessoas iguais em termos de justiça é o compartilhamento de qualidades distintas de humanidade, como autonomia, racionalidade, domínio do idioma, a capacidade de estruturar e seguir um conceito do bem, ou a vulnerabilidade a feridas morais. ${ }^{30}$

Pelo fato se esse método definir quadros na base da pessoa, ele oferece um recurso para controlar o nacionalismo exclusivista. No entanto, a sua abstração também representa a sua fraqueza. Alheio a relações históricas e sociais, preconiza a aceitação indiscriminada de todos em relação a tudo. A adoção de um quadro que aceita a todos em termos de humanidade global, elimina o reconhecimento de que questões diferenciadas que possam requerer quadros ou escalas diferentes na aplicação da justiça.

29 Para a versão cidadã do princípio da afiliação, leia John RAWLS, O Direito dos Povos, Cambridge : Cambridge, 1999; KYMLICKA, Delimitações Territoriais: Uma Perspectiva Liberal e Igualitária, em Divisas e Justiça: Perspectivas Éticas Divergentes, Princeton: ed. David Miller e Sohail H. Hashmi, 2001, p. 249-75, e Thomas NAGEL, O Problema da Justiça Global, Filosofia e Relações Públicas 33, primavera 2005, p. 113-47. Para a vertente de nacionalidade, leia MILLER, A Respeito da Nacionalidade Oxford : Oxford, 1995, esp. cap. 3.

30 Os defensores desta abordagem incluem Martha Nussbaum, leia o seu "Patriotismo e Cosmopolitismo", em Martha C. NUSSBAUM et al., Por Amor à Pátria:. Debatenfo os Limites do Patriotismo, Boston : ed. Joshua Cohen, 1996, p. 2-17. 
É compreensível, então, que um outro grupo de filósofos e ativistas rejeitem tanto a filiação nacionalista exclusivista quanto o globalismo abstrato do humanismo. Com o intuito de formar um conceito de justiça transnacional, os proponentes do princípio de todos-afetados sugerem que se resolvam as disputas quanto ao "quem" da justiça voltando-se para as relações de interdependência social. Para eles, por conseguinte, o que caracteriza um grupo de pessoas como iguais perante a justiça é o seu entrelaçamento objetivo numa rede de relacionamentos. ${ }^{31}$ Esse método tem o mérito de oferecer um dispositivo crítico para evitar noções de proveito pessoal de filiação, enquanto também toma conhecimento de relações sociais. Porém, ao conceber de relacionamentos de forma objetivista, em termos de casualidade, a escolha do "quem" fica, sem efeito, relegada ao estudo das ciências sociais principais. Além do mais, o princípio de todos-afetados cai vítima ao reductio ad absurdum do efeito borboleta, que prega que todos são afetados por tudo. Incapaz de identificar relações sociais moralmente relevantes, reluta em resistir à prática do "o que é bom para um, também serve para outro" do globalismo, que tanto tentou evitar. Assim, também fracassa na tentativa de oferecer um padrão defensável na determinação do "quem" em tempos anormais.

Dadas as respectivas deficiências em termos de filiação, humanismo e a medida de quanto se é afetado, que tipo de princípio determinante pode nos ajudar a avaliar quadros antagônicos na justiça anormal? Eu proponho submeter alegações de mal-enquadramento ao princípio que eu chamo de afeta-a-todos. De acordo com esse princípio, todos aqueles subordinados a uma certa estrutura em matéria de governança possuem uma postura moral como pessoas sujeitas à sua justiça. Nesse ponto de vista, o que faz com que um grupo de pessoas esteja no mesmo nível em relação à justiça não é nem a cidadania nem a nacionalidade, nem mesmo a posse de qualidades humanas abstratas, ou o simples fato de interdependência casual, mas sim a sua subordinação conjunta a uma estrutura de governança que dita as regras que definem a sua interação. Para qualquer que seja a estrutura de governança, o princípio do afeta-a-todos nivela o escopo de preocupação moral desta subordinação. ${ }^{32}$

31 Os defensores desta abordagem incluem Peter Singer, Pogge, e Iris Marion Young. Ver Peter SINGER, Um Mundo: A Ética da Globalização, Yale: New Haven, 2004; Pogge, Pobreza Mundial e Direitos Humanos:Responsabilidades Cosmopolitas e Reformas Cambridge: Cambridge, 2002, e Iris Marion YOUNG, Responsabilidade e Justiça Global: Um Modelo de Conexão Social, Filosofia Social e Política 23, n. 1, 2006, p. 102-30. Até recentemente, eu mesma considerava o princípio do todos-afetados o candidato mais promissor como opção de um novo quadro sucessor do "princípio de pós-Westfaliano", apesar de minhas críticas a sua interpretação cientificista padrão e a sua indeterminação do tipo efeito borboleta, conforme explicado abaixo. Agora, porém, acredito que estas dificuldades são tão graves que o caminho mais sábio é abandonar o princípio todo-afetado em favor da alternativa aqui apresentada. Para os meus pontos de vista anteriores, leia FRASER, Justiça Democrática em uma Era de Globalização: Tematizando o Problema do Quadro, em Versões de Geração do Mundo: Além da Globalização, Liverpool: ed. Nathalie Karagiannis e Peter Wagner, 2007, p. 193-215 e "Reenquadrando a Justiça em um Mundo Globalizado".

32 A expressão "princípio de todos-subordinados" é de minha autoria, mas a idéia pode ser encontrada em Cohen e Charles SABEL, Extra Rempublicam Nulla Justitia? Filosofia e Relações Públicas 34, abril 2006, p. 147-75, FORST, "Justiça, Moralidade e Poder no Contexto Global”. 
É evidente que tudo depende de como interpretamos a frase "subordinado a uma estrutura de governança". Entendo esta expressão de forma ampla, abrangendo relações entre poderes de vários tipos. Não restritas a estados, estruturas de governança também englobam agências não estaduais que geram regras executáveis e que definem importantes áreas de interação social. Os mais óbvios exemplos são as agências que definem as regras da economia global, tais como a Organização do Comércio Mundial e do Fundo Monetário Internacional. Mas muitos outros exemplos poderiam ser citados, inclusive agências transnacionais incumbidas de regulamentar questões de meio ambiente, de energia nuclear, policiamento, segurança, saúde, propriedade intelectual, além da administração da justiça civil e criminal. Enquanto cumprem suas funções de regular a interação de grandes populações transnacionais a elas subordinadas, as agências reguladoras não têm responsabilidades em relação àqueles que elas governam. Dada essa visão ampla de estruturas de governança, o termo subordinado deve ser aplicado da mesma forma ampla. Não restrita à cidadania formal ou até à condição mais ampla de estar subordinada à jurisdição de um estado, essa noção também pode incluir a condição de estar sujeita ao poder coercivo de formas de governo que não estaduais e trans-estaduais.

Sob este prisma, o princípio do afeta-a-todos oferece um padrão crítico para a avaliação de quadros de justiça. Uma questão é enquadrada de forma justa se, e apenas se todos subordinados a uma (ou mais) estrutura(s) de governança reguladoras de um (ou mais) segmento(s) relevante(s) de interação social recebem a mesma consideração. Saliente-se que, para merecer esta consideração, não é preciso já estar afiliado à estrutura em pauta; é apenas necessário estar sujeito a ela. Assim, os africanos do sul do Saara que foram involuntariamente excluídos da economia global como resultado de regras impostas por suas estruturas de governança estão sujeitos a essa justiça, apesar de não serem reconhecidos como participantes na questão. ${ }^{33}$

O princípio do afeta-a-todos remedia os principais defeitos dos princípios anteriores. Diferente da filiação, ele trespassa a armadura dos interesses corporativistas de nacionalismo exclusivista para poder contemplar injustiças de mal-enquadramento. Diferente do humanismo, supera o globalismo abstrato e acolhedor de todos ao reconhecer os relacionamentos sociais. Diferente da questão do quem-afeta, evita a generalidade do efeito borboleta, identificando formas relevantes de interação social, ou seja, a subordinação conjunta a estruturas de governança. Longe de aceitar um "quem" global, no caso do "quem" westfaliano, o princípio do todos-subordinados milita contra a solução-aceitável-para-todos.

33 Leia James FERGUSON, Apatia Global: Abjeção e as Consequências do Modernismo, Expectativas da Modernidade: Mitos e Significados da Vida Urbana na Região do Cobre da Zâmbia Berkeley: Berkeley, 1999, p. 234-54. 
No mundo atual, todos nós estamos sujeitos a uma pluralidade de estruturas de governança diferentes, algumas locais, algumas nacionais, algumas regionais e algumas globais. A necessidade é, por conseguinte, de se delimitar um conjunto de quadros para diferentes questões. Capaz de identificar uma pluralidade de "quens" para diferentes finalidades, o princípio do todos-subordinados nos diz quando e onde aplicar qual quadro - e, assim, define quem tem o direito à paridade de participação com quem em determinadas circunstâncias.

Também para esta proposta, no entanto, os detalhes são menos importantes do que a estrutura conceitual. O que é crucial aqui é que esta abordagem combine um questionamento reflexivo de quadros de justiça com um princípio de avaliação determinante. Dessa forma, vale a pena atentar para ambos os lados da justiça anormal (Abnormal Justice), tanto para o negativo quanto para o positivo. Graças à sua reflexividade, o conceito de mal-enquadramento valida contestações do quadro westfaliano. Por ser elevado ao nível meta, esse conceito permite que imaginemos a possibilidade de que questões de primeira ordem de justiça tenham sido enquadradas de forma injusta. Ao mesmo tempo, graças ao seu caráter determinante, essa abordagem oferece uma forma de avaliar a justiça de vários "quens". Ao submeter os quadros propostos ao princípio do todos-subordinados, podemos avaliar os seus méritos relativos. Assim, essa abordagem oferece boas perspectivas para o esclarecimento de disputas quanto aos vários "quens" em tempos anormais.

E ainda existe outra questão capital. Como exatamente devemos implementar o princípio do todos-subordinados? Através de que procedimentos e processos podemos aplicar esse princípio para resolver disputas quanto a quem conta em tempos anormais? Se não encontrarmos uma forma adequada de lidar com o "como" da justiça, essa abordagem do "quem” não nos será útil.

\subsection{O "Como" da justiça: institutionalizando a meta-democracia}

Isso me leva, finalmente, ao problema do "como". Para essa questão, também, o truque é de considerar tanto o lado positivo quanto o lado negativo da justiça anormal. Que tipo de formulação de teorias de justiça pode valorizar o aumento de contestações, enquanto também esclarece disputas onde não existe um conceito compartilhado do "como" da justiça? A resposta curta é a formulação que é, ao mesmo tempo, dialógica e institucional.

Permita que eu explique.

Para valorizar o aumento das contestações, a teoria de justiça para tempos anormais deve renunciar a duas abordagens que já emergiram em considerações anteriores. Primeiramente, deve suspender a pressuposição hegemônica de que 
estados poderosos e elites privadas devem determinar a gramática da justiça. Conforme vimos, essa visão era inconteste na justiça normal, quando discussões quanto ao "quem" eram tão raras e restritas que podiam ser resolvidas a portas fechadas. Hoje, no entanto, à medida que movimentos sociais contestam o quadro westfaliano, eles estão desafiando tais prerrogativas com o simples fato de tratar a questão do quadro como um tema próprio de uma ampla discussão pública. Ao reivindicar o direito de determinar o "quem", simultaneamente problematizam o "como" hegemônico. À parte de suas outras demandas, então, esses movimentos fazem efetivas demandas por algo mais: a criação de procedimentos novos, não hegemônicos para lidar com disputas de enquadramento de justiça em tempos anormais. Essa demanda também merece ser ouvida de forma justa. Para evitar a sua rejeição antecipada, a teoria de justiça para tempos como esses deve acolher perspectivas não padronizadas do "como".

Segundo, a teoria de justiça para tempos anormais deve rejeitar o que eu vou chamar de pressuposição científica. Considerado por alguns proponentes do princípio do afeta-a-todos, o conceito do "como" da justiça afirma que decisões quanto ao quadro devem ser determinadas pela ciência social normal, que se pressupõe esteja de posse de fatos incontroversos quanto a quem é afetado e por que; nesse sentido, quem merece consideração quanto a quais questões. Na justiça anormal (Abnormal Justice), no entanto, disputas quanto ao quadro não se reduzem à simples questão de fatos empíricos; já que interpretações de historiadores, teorias sociais, e pressuposições normativas que estão necessariamente na base de reclamações factuais também estão em discussão. ${ }^{34}$ Sob condições de injustiça, podemos acrescentar, o que passa por "ciência" social estabelecida, pode muito bem refletir as perspectivas, e entrincheirar pontos cegos, dos privilegiados.

Nestas condições, a adoção de pressuposições científicas traz o risco de rejeitarmos as reivindicações dos desfavorecidos. Assim, a teoria em linha com o aumento de contestações deve rejeitar essa pressuposição. Sem negar a relevância do conhecimento social, deve recusar qualquer sugestão de que disputas quanto ao "quem" sejam resolvidas por "tecnocratas da justiça". 35

Que outras possibilidades existem? Apesar da diferença que os separa, a pressuposição hegemônica e a pressuposição científica têm uma premissa em comum. Ambas se propõem a solucionar a questão de enquadramento de forma monológica, apelando para uma autoridade (de um lado, o poder, de outro, a ciência) que não pode ser responsabilizada em relação a negociações discursivas do debate político. A teoria de justiça para tempos anormais deve rejeitar essa premissa

34 Leia FRASER, Justiça Democrática na Era Globalizada, em Versões de Geração do Mundo: Além da Globalização, Liverpool: ed. Nathalie Karagiannis e Peter Wagner, 2007, p. 193-215

35 Um argumento semelhante é encontrado em Amartya SEN, Desenvolvimento como Liberdade. Nova York: New York University Press, 1999. 
monológica. Para validar a contestação, deve tratar de disputas de enquadramento de forma dialógica, como conflitos políticos cuja solução legítima requer uma discussão pública inclusiva e sem barreiras. Rejeitando apelos às autoridades, formulações de teorias de justiça anormal devem vislumbrar um processo dialógico para a aplicação do princípio todos-subordinados a questões do "quem".

Assim, uma teoria de justiça para tempos anormais deve ser dialógica. Por si só, no entanto, o diálogo não é uma solução. A partir do momento que aceitamos que conflitos de enquadramento devam ser tratados através do discurso, devemos imaginar uma forma em que o debate público quanto ao "quem" possa criar soluções executáveis. $\mathrm{Na}$ falta de uma versão da relação entre contestação e a legitimidade de decisões, não temos meios de implementar o princípio do todos-subordinados, portanto, não temos meios de processar disputas de justiça anormal.

Como devemos conceber essa relação? Uma abordagem, que pode ser chamada de populismo, colocaria o nexo da contestação e da decisão na sociedade civil. Assim, essa abordagem delegaria a função de aplicar o princípio do todossubordinados a movimentos sociais ou arenas discursivas como o Fórum Social Mundial. ${ }^{36}$

Apesar de aparentemente satisfazer a questão do dialoguismo, o populismo é, no entanto, insatisfatório, pelo menos, por duas razões. Primeiramente, até as melhores entidades da sociedade civil têm representatividade suficiente ou são suficientemente democráticas para legitimar suas propostas de reenquadramento da justiça. Segundo, falta a essas entidades a capacidade de assegurar a obrigatoriedade de decisões políticas. Ou seja, apesar de poder apresentar novos elementos em termos de reivindicações para um debate público, por si só, agentes da sociedade civil não têm os meios de garantir as reclamações nem a obrigatoriedade das decisões tomadas.

Essas limitações sugerem a necessidade de um segundo trilho no processo dialógico, um trilho institucional formal. Esse segundo trilho do processo dialógico deve se posicionar de forma dinâmica e interativa em relação ao primeiro trilho. Concebido como um pólo de um processo comunicativo bidirecional,

36 Para uma variante influente do populismo, leia Michael HARDT e Antonio NEGRI, Empire Cambridge: Cambridge, 2000. Para uma variante menos romântica, leia o trabalho recente de Bohman, que parece sustentar que a contestação da esfera pública por si só pode sanar os conflitos sobre o "quem”, portanto, que nenhuma instituição política cosmopolita é necessária para o propósito. Uma visão semelhante é endossada por Seyla Benhabib, que é em outros aspectos, longe de populista, mas que também parece colocar todo o ônus da resolução de disputas sobre o "quem” em "interações democráticas" conduzidas na sociedade civil. Leia BOHMAN, Do Demos ao Demoi: Democracia Atravessando Fronteiras, Ratio Juris 18, Set. 2005, p. 293-314 e O Mínimo Democrático: Seria a Democracia um Meio para a Justiça Global? Ética e Relações Internacionais $19^{\circ}$, n. 1, 2005, p. 101-16, e BENHABIB, Palestras de Berkeley Tanner, em Outro Cosmopolita, Oxford: ed. Robert Post, 2006. 
o trilho institucional formal deve ser sensível ao trilho da sociedade civil. ${ }^{37}$ Mas deve divergir dele em dois quesitos. Primeiro, o trilho institucional requer procedimentos justos e uma estrutura representativa para garantir a legitimidade democrática de suas deliberações. Segundo, os representantes, enquanto podem ser responsabilizados através de publicidade e de pleitos, devem ter a capacidade de garantir a obrigatoriedade de suas decisões quanto ao "quem" que refletem o julgamento gerado de forma comunicativa de "quem", de fato, está subordinado a uma determinada estrutura de governança.

O resultado é que a justiça anormal (Abnormal Justice) requer a invenção de novas instituições democráticas globais onde disputas quanto a enquadramento podem ser colocadas no ar e resolvidas. Presumindo que essas disputas não vão desaparecer tão cedo e podem não estar suscetíveis a uma solução definitiva e final, a abordagem que eu recomendo encara-as da perspectiva de uma questão perene da vida política num mundo em processo de globalização. Assim, defende novas instituições como fórum democrático de resoluções provisórias de disputas, em permanente diálogo com a sociedade civil transnacional.

Certamente, muito mais precisa ser dito em termos da estrutura e da dinâmica desses fóruns. Mas nesse caso, também, os detalhes são menos importantes do que a estrutura conceitual global da proposta. O que é de suma importância aqui é que essa visão do "como" da justiça combine quesitos dialógicos e institucionais. Conseqüentemente, vale atentar para os dois lados da justiça anormal, o negativo assim como o positivo. Graças a seu dialoguismo, valida contestações de parâmetros de justiça previamente não questionadas. Rejeitando a visão monológica, procura proporcionar uma audiência justa para questões que a hegemonia de cientificismo rejeita. Ao mesmo tempo, graças a seus dois trilhos, supera a carência em termos de decisões e legitimidade do populismo. Ao submeter metareivindicações para o reenquadramento da justiça a um processo em dois trilhos de comunicação entre a sociedade civil e novas instituições de representatividade global, vislumbra procedimentos para a implementação do princípio todos-subordinados em contextos de discordância quanto ao "quem". Assim, essa abordagem se candidata a resolver provisoriamente conflitos de enquadramento em condições de justiça anormal.

Mas isso não é tudo. Ao oferecer um meio de destrinchar metaproblemas, esta proposta abre o caminho para as importantes questões de primeira ordem com as quais começamos. Ao solucionar questões de injustiça de mal-enquadramento,

37 Para uma versão de comunicativa-teórica do modelo em duas vertentes, leia Jürgen HABERMAS, Entre Fatos e Normas: Contribuições para uma Teoria do Discurso do Direito e da Democracia, trad. William Rehg, Cambridge: Cambridge, 1996. Para uma crítica do enquadramento tácito Westfaliano desta versão, leia FRASER, “Transnacionalizando a Esfera Pública: Sobre a Legitimidade e a Eficácia da Opinião Pública em um Mundo Pós-Westfáliano”, Teoria, Cultura e Sociedade 24, número 4,2007, p. 7-30. 
simultaneamente, abre-se o caminho para lidar com injustiças em termos de mádistribuição, mal-reconhecimento e má-representação. Assim, essa abordagem nos possibilita vislumbrar cenários políticos para superar ou reduzir injustiças em tempos anormais.

É com o objetivo de incentivar essa questão que eu expus o argumento dessa seção. Eu tenho discutido aqui que a teoria da justiça adequada a condições de discurso anormal (Abnormal Discourse) deve incluir três elementos. Primeiro, essa teoria deve compreender uma interpretação do "o quê" da justiça, que é multidimensional na ontologia social e normativamente monista - por exemplo, uma interpretação que submete reivindicações quando a redistribuição, reconbecimento e representação política ordinária ao princípio de participação em paridade.

Segundo, esta teoria deve abranger uma visão do "quem" que é, ao mesmo tempo, reflexivo e determinante-por exemplo, uma visão que submete reivindicações contra injustiças de mal-enquadramento ao princípio do todos-subordinados. Finalmente, a teoria de justiça para tempos anormais deve abranger uma visão do "como" que é, simultaneamente, dialógica e institucional - por exemplo, uma visão que vislumbra novas instituições representativas globais onde reivindicações metapolíticas podem ser submetidas a procedimentos deliberativos e democráticos de tomada de decisão.

Mais importante do que essas questões específicas, no entanto, é o problema geral aqui delineado. Sob condições de justiça anormal, pressuposições previamente intocáveis em relação ao "o quê", ao "quem" e ao "como" deixam de ser inquestionáveis. Assim, essas próprias pressuposições devem se sujeitar a discussões e reavaliações. Nessas discussões, o truque é evitar duas possibilidades. De um lado, devemos resistir à tentação reacionária e basicamente fútil de nos apegar a pressuposições que não se apropriam mais ao nosso mundo em processo de globalização, como a distribuição redutivista e o westfalianismo obsoleto. De outro lado, devemos evitar a celebração da anormalidade em si, como se a contestação fosse em si uma liberação. Nessa seção, eu procurei modelar um posicionamento alternativo, que reconhece justiça anormal como o horizonte dentro do qual todas as batalhas contra injustiças devem ocorrer. Apenas pela apreciação dos perigos e potenciais desta condição é que podemos almejar a redução das enormes injustiças que permeiam o nosso mundo. 


\section{Uma nova justiça normal ou reflexiva? Concluindo reflexões conceituais e reflexivas}

Antes de concluir, quero considerar algumas das implicações conceituais e políticas mais amplas do meu argumento geral. Até aqui, minha discussão englobou duas partes heterogêneas, uma diagnóstica e a outra reconstrutiva.

Na primeira seção, a diagnóstica, eu caracterizei o presente como uma era de justiça anormal em que os parâmetros básicos de contestação política estão indefinidos. Identificando três núcleos distintos de anormalidade, mapeei os contornos de uma formação (westfaliana-distributivista) discursiva no processo de desnormalização. Na segunda seção, a reconstrutiva, propus três estratégias correspondentes para a reflexão sobre a justiça em tempos anormais. Notando que nossas teorias familiares de justiça pressupõem condições de discurso normal, procurei desenvolver modelos alternativos de formulações de teorias mais apropriadas a um contexto em que existam divergências em relação ao "o que", ao "quem", e ao "como" da justiça. Dada a heterogeneidade destas duas partes do meu argumento, a questão se coloca quanto à relação entre elas. Que aspirações conceituais em termos de lógica e política conecta a minha Zeitdiagnose (Diagnóstico do tempo) da presente conjuntura com minhas tentativas de reconstrução teórica? ${ }^{38}$

Duas possibilidades se apresentam. Numa leitura, as características negativas da justiça anormal são empecilhos graves o suficiente para brecar a luta contra injustiças, merecendo medidas de re-normalização. Essa visão enfatiza a impossibilidade de mudanças emancipatórias na ausência de um quadro relativamente estável para a análise e retificação de reivindicações. Dadas essas circunstâncias, o objetivo deve ser o da reconstrução deste quadro em termos da conjuntura atual. O resultado, em condições favoráveis, seria um novo paradigma de discurso normal de justiça, com premissas numa nova interpretação do "o quê", do "quem" e do "como" mais apropriados ao mundo em processo de globalização. Nessa leitura, portanto, minha proposta específica se voltaria para a construção desse paradigma. A razão de tal exercício seria o desenvolvimento de um novo normal.

Certamente, a opção poderia ser bem pior do que a redefinição de um novo normal capaz de reenquadrar conflitos de justiça de maneiras condizentes com um mundo em processo de globalização. No entanto, restam razões para duvidar que esta abordagem represente a melhor opção para a presente situação. Como exemplo, a renormalização se arrisca a fechar prematuramente novos caminhos para contestação antes mesmo de elas terem uma oportunidade justa de

38 Meus agradecimentos aos muitos interlocutores que levantaram essa questão, especialmente à Nancy Rosenblum, cuja formulação caracteristicamente forte e nítida tornou a questão impossível de se ignorar. 
estabelecer a sua plausibilidade. Outro exemplo seria o risco de se adotar uma nova predefinição restritiva do que é uma reivindicação inteligível e válida de justiça, criando redutos para novas exclusões. Finalmente, a proposta de estabelecer um novo normal ameaça sacramentar um conjunto fixo de pressuposições de justiça numa encruzilhada histórica, ao passo que as circunstâncias da justiça estão num estado fluído e necessitam de flexibilidade.

Por todas essas razões, vale a pena considerar outra leitura da argumentação geral exposta aqui.

A segunda leitura que tenho em mente vislumbra um resultado que estremece a distinção entre justiça normal (Normal Justice) e anormal (Abnormal Justice). Na base das carências de cada um desses gêneros de discurso, essa leitura procura um modelo alternativo que evita seus defeitos enquanto seleciona os melhores elementos de cada. Contrastando com o discurso anormal, o modelo almejado seria o suficientemente capaz de se estruturar como fórum para as batalhas e argumentações jurídicas em que as partes se confrontam demandando a atenção e o julgamento daqueles presentes. Diferente do discurso normal, no entanto, esse modelo seria suficientemente capaz de se auto-problematizar para acolher novas reivindicações quanto ao "o quê", ao "quem" e ao "como". Ao combinar elementos de discurso normal e anormal, o resultado seria uma gramática de justiça intrinsecamente voltada para a conclusão, que é necessária ao argumento político, mas tratando cada conclusão como provisória sujeita a questionamento, possível suspensão, e assim, à reabertura. Pregando a ação em relação a exclusões emergentes, um modelo como esse incluiria conceitos como o mal-enquadramento que convidam à auto-problematização reflexiva voltado à exposição de injustiças previamente ocultas. Nessa leitura, o objetivo de todo o exercício não seria nem a revelação na anormalidade nem a apressada instalação de um novo normal. Seria sim o de desenvolver um terceiro gênero de discurso que poderíamos chamar de justiça reflexiva (Reflexive Justice).

A idéia da justiça reflexiva se encaixa bem no contexto atual de discurso anormal. Nesse contexto, "o quê", o "quem" e o "como" não têm grandes perspectivas de se resolverem tão cedo. Assim, faz sentido encarar os três núcleos de anormalidade como elementos perenes do discurso jurídico por algum tempo. De outro lado, dada a importância de injustiças de primeira ordem nos dias de hoje, a pior resposta possível seria a de tratar as metadisputas atuais como uma licença para a paralisia. Por conseguinte, é de suma importância não permitirmos que anormalidades discursivas posterguem ou dissipem os esforços de remediação de injustiças. A expressão justiça reflexiva (Reflexive Justice) expressa esse compromisso duplo, indicando um gênero de formulação de teorias que funciona em dois níveis ao mesmo tempo: lidando com reivindicações urgentes por parte dos desventurados enquanto também analisa as metadiscórdias entrelaçadas a elas. Por estarem esses dois níveis definitivamente 
emaranhados em tempos anormais, formulações de teorias de justiça reflexiva não podem ignorar nem uma nem outra. Agindo na intersecção entre as duas e manobrando no espaço entre elas, essa formulação teórica aciona as capacidades de correção de uma para diminuir os defeitos da outra. Desta forma, indefine a distinção entre discurso normal e anormal. ${ }^{39}$

Por essas razões, prefiro interpretar o télos da minha argumentação geral não como um novo normal, mas como uma espécie de justiça reflexiva. ${ }^{40}$ Essa leitura tem duas implicações adicionais que merecem consideração. A primeira diz respeito à conhecida oposição na filosofia política entre abordagens ético-discursivas, de um lado, e abordagens agnósticas, de outro lado. Corretamente ou não, as primeiras são caracterizadas como cultuadoras da anormalidade. ${ }^{41}$ Sem falsas pretensões de avaliar os méritos dessas alegações e suas respectivas réplicas, proponho que a idéia de justiça também embaralha essa oposição. Da mesma forma dos modelos agnósticos, a justiça reflexiva valoriza o momento de abertura, que rompe as exclusões da justiça normal, acolhendo seus reclamantes antes silenciados e expondo injustiças de sua responsabilidade - todas elas essenciais para a contestação de injustiças. Assim como a ética do discurso, no entanto, a justiça reflexiva também valoriza o momento do fechamento, que possibilita o argumento político, a tomada de decisão

39 Meu interesse atual em embaralhar a distinção entre o discurso normal e o anormal está representado em minhas comunicações anteriores com Rorty. Em um ensaio de 1988, notei em Rorty a tendência para alinhar o discurso anormal com "ironia privada" e o discurso normal, com "solidariedade pública ", e eu propus que a crítica social radical minavam essas dicotomias na medida em que era, ao mesmo tempo, anormal e solidária; leia FRASER, Solidariedade ou Singularidade? Richard Rorty entre o Romantismo e a Tecnocracia, Praxis International 8, outubro 1988, p. 257-72. Mais tarde, em sua palestra Tanner de 1991 (Feminismo e Pragmatismo), Rorty provocativamente transgrediu o seu alinhamento original com sua leitura da segunda onda do feminismo radical como anormal e publicamente relevante. Em minha resposta. FRASER, De Ironia à Profecia à Política: Uma Resposta a Richard Rorty, Michigan Quarterly Review 30, Primavera 1991, p. 259-66, aplaudi esse movimento, ao mesmo tempo em que eu culpei a esposição de Rorty por individualizar e estetizar o processo de inovação lingüística no feminismo, portanto, por negligenciar seu caráter coletivo e democrático. Esse argumento me parece agora, em retrospecto, como presságio da minha proposta atual de abalar a distinção entre o discurso normal e o anormal.

40 Claramente, esta preferência por justiça reflexiva também me distingue de defensores do discurso anormal, paradigmaticamente Jean-François LYOTARD, O Diferendo: Frases em Disputa, trad. Georges Van Den Abbeele Minneapolis: U of Minnesota P, 1988. Meus agradecimentos a Vincent Descombes pela comparação com Lyotard.

41 Críticas clássicas da ética do discurso do ponto de vista do agonismo incluem LYOTARD, A Condição Pós-moderna: Um Relatório sobre o Conhecimento, trad. Geoff Bennington e Brian Massumi. University of Minnesota: Minneapolis, 1984, e Chantal MOUFFE, Democracia Deliberativa ou Pluralismo agonístico? Social Research 66, Outono 1999, p. 745-58. Versões clássicas da crítica do discurso de ética do agonismo incluem HABERMAS, O Discurso Filosófico da Modernidade: Doze Palestras, trans. Frederick G. Lawrence, Cambridge: Cambridge, 1987) e BENHABIB, Epistemologias do Pósmodernismo: Uma Tréplica a Jean-François Lyotard, New German Critique 33, outono 1984, p. 103-26. Para uma recente rodada de debate, leia o diálogo entre Benhabib e Bonnie Honig em BENHABIB, Outro Cosmopolitismo. 
coletiva e a ação pública - todos considerados por ela como indispensáveis para uma justiça reparatória. Procurando acomodar os momentos, tanto de abertura quanto de fechamento, a justiça reflexiva interpreta a oposição-padrão entre agonismo e a ética do discurso como uma antítese falsa. Recusando-se a tomar qualquer um dos modelos como absolutos e evitando a exclusão da perspectiva do outro, ele seleciona elementos de cada para criar um novo gênero de formulação de teorias para tempos anormais.

A segunda consequência diz respeito à relação entre as problemáticas da justiça anormal e da hegemonia. Como é sabido, a teoria da hegemonia conceitualiza uma segunda face discursiva do poder ao lado da repressão bruta. Essa segunda face inclui a capacidade de construir um "senso comum" para uma grande variedade de eleitorados, induzidos pelo agente hegemônico a uma visão política universal compartilhada. Dentro desse universo, cada eleitor é capaz de se reconhecer como um subordinado político e de formular seus interesses e metas de uma forma inteligível a outros. ${ }^{42}$ Nesta perspectiva, a hegemonia inclui a capacidade de definir a legitimidade do universo de desavenças políticas enquanto simultaneamente constitui o exterior destes como uma região de ininteligibilidade. ${ }^{43}$ Esse ponto também pode ser colocado da seguinte forma: ao instituir um conjunto de pressuposições fundamentais estruturais, o que em si é evidente, a hegemonia predetermina o que se caracterizará ou não como uma reivindicação jurídica plausível. Vista sob esse prisma, a teoria da hegemonia tem afinidades claras com a problemática elaborada aqui. Em seus termos, episódios de justiça normal corresponderiam a períodos de hegemonia relativamente seguros e incontestes em que reclamações alheias ao senso comum permanecem dispersas, deixando de formar um bloco contrário à hegemonia. Em contraste, episódios de anormalidade corresponderiam a períodos de luta aberta por hegemonia em que formações anti-hegemônicas atingem uma liga suficientemente forte para problematizar o que se passava previamente por evidente. Afinidades de lado, no entanto, a problemática da hegemonia sugere uma visão histórica diferente das anormalidades atuais. Sob o seu ponto de vista, estas se originam menos do processo impessoal da globalização do que ao declínio da hegemonia americana desde o colapso da URSS, em 1989. Levando-se em conta que a hegemonia americana se apoiava na Guerra Fria, a queda dessa ordem geopolítica apresentou um desafio à gramática de justiça (westfaliana-distributivista) que definia o "mundo livre". Seguindo o fracasso na articulação de um senso comum plausível

42 Para as relatos clássicos de hegemonia, leia Antonio GRAMSCI, Prison Notebooks, trans. Joseph A. Buttigieg e Antonio CALLARI, Nova York: ed. Buttigieg, 3 vols., 1992-2007, e Ernesto LACLAU e MOUFFE, Hegemonia e Estratégia Socialista: Rumo a uma Política Democrática Radical. Londres: Verso, 1985.

43 Para os relatos que enfatizam os aspectos de exclusão de formações discursivas, embora sem referência ao termo hegemonia, leia Pierre BOURDIEU, Linguagem e o Poder Simbólico, trans. Gino Raymond e Mateus Adamson, Cambridge: ed. John B. Thompson, 1991; Judith BUTLER, Discurso Incendiável: Uma Política do Performativo Nova York: Routledge, 1997) e Michel FOUCAULT, Obras Essenciais de Foucault, 1954-1984, Nova York: ed. Paul Rabinow, 3 vols., 1997-2000. 
para o pós-guerra centrado na "guerra ao terror", os americanos, até a presente data, têm se mostrado incapazes de perpetuar a sua hegemonia. O resultado é uma óbvia discrepância entre as duas faces do poder; a supremacia militar americana não tem em contrapartida uma capacidade de estruturar um senso comum compartilhado que possa normalizar conflitos de justiça. Não é de se estranhar, portanto, que o discurso da justiça esteja em processo de desnormalização e que disputas quanto ao "o quê, ao "quem" e ao "como" estão proliferando.

Por mais convincente que seja essa história, não é, de fato, uma rival à que eu desenvolvi aqui. Muito pelo contrário, a perspectiva hegemônica complementa a problemática do discurso (a)normal. Enquanto a anterior interpreta o discurso da justiça historicamente e estrategicamente, almejando compreender mudanças de poder, a segunda promove um questionamento filosófico e normativo, procurando expor possibilidades atuais de mudança emancipatória. Assim, longe de serem mutuamente incompatíveis, estas duas perspectivas se enriquecem na presença da outra. Assim como a teoria hegemônica, o quadro (a)normal reconhece o lado histórico e o poder do discurso de justiça. O que ele acrescenta, no entanto, é uma insistência na necessidade da reconstituição da gramática da justiça para possibilitar ao subalterno que se expresse de forma autoritativa. Dessa forma, a perspectiva aqui desenvolvida oferece um ingrediente crucial à formulação de teorias críticas que a teoria hegemônica por si só não traz: a elusiva, mas inspiradora visão, de um discurso de justiça que poderia expor injustiças contemporâneas como as abominações morais que certamente são. Fornece, nas palavras de Richard Rorty, o ingrediente que faltava em termos de "esperança social". 


\section{Referências}

AMAN, Jr., Alfred C. Globalização, Democracia e a Necessidade de uma Nova Lei de Administração, Indiana Journal of Legal Global Studies 10, Inverno 2003, p. 125-55.

ANDERSON, Elizabeth S. Qual é o Ponto de Igualdade? Ética 109, janeiro 1999, p. 287-337.

ARENDT, Hannah. As Origens do Totalitarismo. Nova York: Columbia University Press, 1973.

BENHABIB, Seyla. Palestras de Berkeley Tanner, em Outro Cosmopolita, Oxford: ed. Robert Post, 2006.

BENHABIB, Seyla. Epistemologias do Pós-modernismo: Uma Tréplica a Jean-François Lyotard, New German Critique 33, outono 1984, p. 103-26.

BOHMAN, Do Demos ao Demoi: Democracia Atravessando Fronteiras, Ratio Juris 18, Set. 2005, p. 293-314.

BOHMAN O Mínimo Democrático: Seria a Democracia um Meio para a Justiça Global? Ética e Relações Internacionais $19^{\circ}$, n. 1, 2005, p. 101-16.

BOURDIEU, Pierre. Linguagem e o Poder Simbólico, trans. Gino Raymond e Mateus Adamson, Cambridge: ed. John B. Thompson, 1991.

BOYCE, James K. Democratizando a Governança Econômica Global, Desenvolvimento e Mudança 35, Junho de 2004, p. 593-99.

BOHMAN, James. Regimes Internacionais e Governança Democrática: IgualdadePolítica e Influência em Instituições Mundiais, International Affairs 75, Julho de 1999, p. 499-513.

COX, Robert W. Democracia em Tempos Difíceis: Globalização Econômica e as Limitações à Democracia Liberal, em A Transformação da Democracia? Cambridge: ed. Anthony McGrew 1997, p. 4972.

COX, Robert W. Uma Perspectiva sobre a Globalização, em Globalização: Reflexões Críticas, Boulder: ed. James H. Mittelman, 1996, p. 21-30.

DRYZEK, John S. A Democracia Transnacional, Journal of Political Philosophy 7, março 1999, p. $30-51$.

DWORKIN, Ronald O que é a Igualdade? Parte 2: Igualdade de Recursos, Filosofia e Relações Públicas, 10, Outono 1981, p. 283-345.

FERGUSON, James, Apatia Global: Abjeção e as Consequências do Modernismo, Expectativas da Modernidade: Mitos e Significados da Vida Urbana na Região do Cobre da Zâmbia Berkeley: Berkeley, 1999 , p. 234-54.

FORST, Rainer. Justiça, Moralidade e Power e no Contexto Global, em Justiça no Mundo Real: Fundamentos, Princípios, Direitos Humanos, e as Instituições Sociais, Dordrecht, Holanda: ed. Andreas Follesdal e Pogge, 2005, p. 27-36.

FORST, Rainer. Para uma Teoria Crítica de Justiça Transnacional, em Justiça Global, Oxford: ed. Pogge, 2001, p. 169-87

FOUCAULT, Michel. Obras Essenciais de Foucault, 1954-1984, Nova York: ed. Paul Rabinow, 3 vols., 1997-2000.

FRASER, Nancy. Transnacionalizando a Esfera Pública: Sobre a Legitimidade e a Eficácia da Opinião Pública em um Mundo Pós-Westfáliano, Teoria, Cultura e Sociedade 24, número 4, 2007, p. 7-30.

FRASER, Nancy. Justiça Democrática em uma Era de Globalização: Tematizando o Problema do Quadro, em Versões de Geração do Mundo: Além da Globalização, Liverpool: ed. Nathalie Karagiannis e Peter Wagner, 2007, p. 193-215.

FRASER, Nancy. Identidade , Exclusão e Crítica: Uma Resposta a quatro críticos, European Journal of Political Theory 6, julho 2007, p. 305-38.

FRASER, Nancy. A Política do Enquadramento: Uma Entrevista com Nancy Fraser. - Entrevista de Kate Nash e Vikki Bell, Teoria, Cultura e Sociedade 24, número. 4 2007, p. 73-86.

FRASER, Reenquadrando a Justiça num Mundo Globalizado, New Left Review 36, novembrodezembro 2005, p. 69-88.

FRASER, Nancy e HONNETH, Axel Redistribuição ou Reconhecimento? Um Intercâmbio Político-Filosófico, trad. Joel Golb, James Ingram, e Christiane Wilke, London: Verso, 2003.

FRASER, Nancy. Repensando o Reconhecimento, New Left Review 3, maio-junho 2000, p. 107-20.

FRASER, Nancy. De Ironia à Profecia à Política: Uma Resposta a Richard Rorty, Michigan Quarterly Review 30, Primavera 1991, p. 259-66. 
FRASER, Nancy. Solidariedade ou Singularidade? Richard Rorty entre o Romantismo e a Tecnocracia, Praxis International 8, outubro 1988, p. 257-72.

GILL, Stephen Novo Constitucionalismo, Democratização e Política Econômica Global, Pacific Review 10, fevereiro 1998, p. 23-38.

GUINIER, Lani. A Tirania da Maioria: Justiça Fundamental na Democracia Representativa, Glencoe: The Free Press of Glencoe, 1995.

HABERMAS, Jürgen. Entre Fatos e Normas: Contribuições para uma Teoria do Discurso do Direito e da Democracia, trad. William Rehg, Cambridge: Cambridge, 1996.

HABERMAS, Jürgen. O Discurso Filosófico da Modernidade: Doze Palestras, trans. Frederick G. Lawrence, Cambridge: Cambridge, 1987.

HARDT, Michael e NEGRI, Antonio. Empire Cambridge: Cambridge, 2000.

HARRIS, Richard L. e SEID, Melinda J. Perspectivas Críticas sobre Globalização e o Neoliberalismo em Países em Desenvolvimento, Boston: Brill, 2000.

HELD, David, Cosmopolitismo: Globalização Domesticada? Review of International Studies 29, outubro 2003, p. 465-80, e Responsabilidade Democrática e Eficácia Política da Perspectiva Cosmopolita, Governo e Oposição 39, Primavera 2004, p. 364-391.

HELD, David, Regulando a Globalização? A Reinvenção da Política, International Sociology 15, junho de 2000, p. 394-408.

HELD, David, A Transformação da Comunidade Política: Repensando a Democracia no Contexto da Globalização, em Fronteiras da Democracia, Cambridge: ed. Ian Shapiro e Casiano Hacker-Cordo'n, 1999, p. 84-111.

HELD, David, Democracia e Ordem Global: Do Estado Moderno para Governança Cosmopolita Cambridge, 1995 , p. 99-140.

HELLEINER, Eric. De Bretton Woods a Financas Globais: O Mundo de Cabeça para Baixo, em Economia Política e a Transformação da Ordem Mundial, Nova York: ed. Richard Stubbs e Geoffrey RD Underhill, 1994, p. 163-75.

HOOGVELT, Ankie. Globalização e o Mundo Pós-colonial: a Nova Economia Política do Desenvolvimento, Baltimore: Johns Hopkins University Press, 2001.

GRAMSCI, Antonio Prison Notebooks, trans. Joseph A. Buttigieg e Antonio Callari, Nova York: ed. Buttigieg, 3 vols., 1992-2007.

KYMLICKA, Will. Delimitações Territoriais: Uma Perspectiva Liberal e Igualitária, em Divisas e Justiça: Perspectivas Éticas Divergentes, Princeton: ed. David Miller e Sohail H. Hashmi, 2001, p. $249-75$.

KYMLICKA, Will. Cidadania Multicultural: Uma Teoria Liberal de Direitos das Minorias, Oxford: Oxford, 1995.

KUHN, Thomas S. A Estrutura das Revoluções Científicas, Chicago: University of Chicago Press, 1996.

LACLAU, Ernesto e MOUFFE.. Hegemonia e Estratégia Socialista: Rumo a uma Política Democrática Radical, Londres: Verso, 1985.

LYOTARD, Jean-François. O Diferendo: Frases em Disputa, trad. Georges Van Den Abbeele Minneapolis: U of Minnesota, 1988.

LYOTARD, Jean-François. A Condição Pós-moderna: Um Relatório sobre o Conhecimento, trad. Geoff Bennington e Brian Massumi : U of Minnesota: Minneapolis, 1984.

MILLER, A Respeito da Nacionalidade Oxford : Oxford, 1995, esp. cap. 3.

MOUFFE, Chantal. Democracia Deliberativa ou Pluralismo agonístico? Social Research 66, Outono 1999 , p. $745-58$

NAGEL, Thomas. O Problema da Justiça Global, Filosofia e Relações Públicas 33, primavera 2005, p. 113-47.

NUSSBAUM et al., Martha C. Por Amor à Pátria:. Debatenfo os Limites do Patriotismo, Boston : ed. Joshua Cohen, 1996, p. 2-17.

POGGE, Thomas W. Pobreza Mundial e Direitos Humanos:Responsabilidades Cosmopolitas e Reformas. Cambridge: Cambridge, 2002.

POGGE, Thomas W. A Influência da Ordem Mundial sobre as Perspectivas para uma Verdadeira Democracia em Países em Desenvolvimento, Ratio Juris 14, setembro 2001, p. 326-43.

POGGE, Thomas W. Justiça Econômica e Fronteiras Nacionais, Revision 22, Outono 1999, p. 27-34.

RAI, M. Shirin. "Representação Política, Instituições Democráticas e o Empowerment da Mulher:

O Debate de Cotas na Índia", em Repensando o Empowerment: Gênero e Desenvolvimento em um Mundo Global / Local, Londres: ed. Jane L., 2000.

RAWLS, John. O Direito dos Povos, Cambridge: Cambridge, 1999. 
RITCHIE, R. e Hill, S. Em Defesa da Representação Equitativa, em Os Votos de Quem Contam? Boston: ed. Ritchie e Hill, 2001, pág. 1-33. 231-58.

RORTY, Richard. Feminismo e Pragmatismo, Michigan Quarterly Review 30, Primavera 1991, p.

RORTY, Richard. Contingência, Ironia e Solidariedade, Cambridge: Cambridge University Press, 1989.

RUGGIE, John Gerard. "Territorialidade e Além: Problematizando a Modernidade em RORTY, Richard”. Filosofia e o Espelho da Natureza. Princeton: Princeton University Press, 1979.

Relações Internacionais. Organização Internacional 47, Inverno 1993, p. 139-74.

SABEL, Charles et alli. Extra Rempublicam Nulla Justitia? Filosofia e Relações Públicas 34, abril 2006, p. 147-75.

SCHNEIDERMAN, David. Regras de Investimento e as Regras da Lei, Constellations 8, Dez. 2001, p. 521-37.

SEN, Amartya Desenvolvimento como Liberdade. Nova York: New York University Press, 1999.

SINGER, Peter. Um Mundo: A Ética da Globalização, Yale: New Haven, 2004.

STORM, Servaas e RAO ,J. Mohan. A globalização de Mercado e a Democracia Munidial: Podem as Vertentes se Encontrar?, Desenvolvimento e Mudança 35, Junho de 2004, p. 567-81.

WILLIAMS, Melissa. Voz, Confiança e Memória: Grupos Marginalizados e as Falhas da Representação Liberal. Princeton:N.J., 1998.

YOUNG, Iris Marion. Responsabilidade e Justiça Global: Um Modelo de Conexão Social, Filosofia Social e Política 23, n. 1, 2006, p. 102-30. 